\title{
CONCENTRATIONS AND LOADS OF SELECTED \\ TRACE ELEMENTS AND OTHER CONSTITUENTS IN \\ THE RIO GRANDE IN THE VICINITY OF \\ ALBUQUERQUE, NEW MEXICO, 1994 \\ By Todd Kelly and H.E. Taylor
}

U.S. GEOLOGICAL SURVEY

Open-File Report 96-126

Prepared in cooperation with the CITY OF ALBUQUERQUE PUBLIC WORKS DEPARTMENT

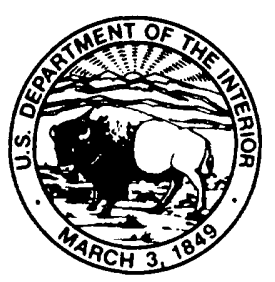

Albuquerque, New Mexico

1996 


\section{U.S. DEPARTMENT OF THE INTERIOR \\ BRUCE BABBITT, Secretary \\ U.S. GEOLOGICAL SURVEY \\ Gordon P. Eaton, Director}

For additional information write to:

District Chief

U.S. Geological Survey Water Resources Division 4501 Indian School Road NE, Suite 200

Albuquerque, New Mexico 87110-3929
Copies of this report can be purchased from:

U.S. Geological Survey Earth Science Information Center Open-File Reports Section Box 25286, MS 517 Denver Federal Center Denver, Colorado 80225 


\section{CONTENTS}

Page

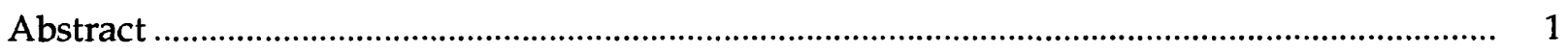

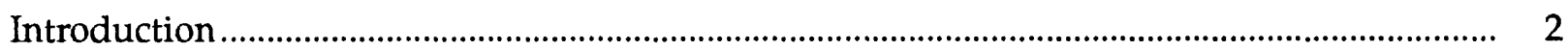

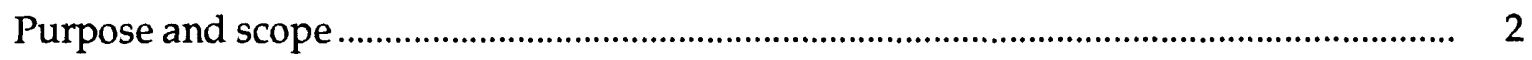

Description of sampling sites ...................................................................................... $\quad 4$

Acknowledgments ......................................................................................................

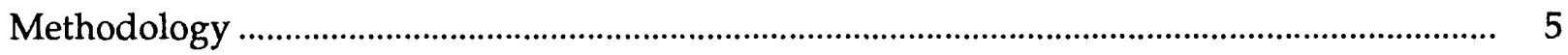

Sample collection ……............................................................................................ 5

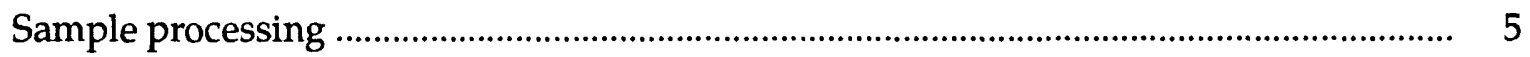

Analytical methods ................................................................................................................ 9

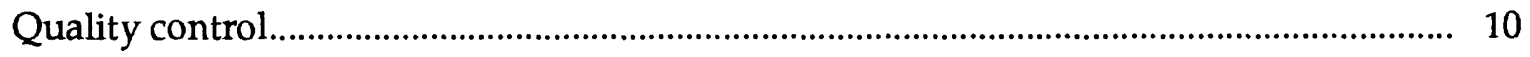

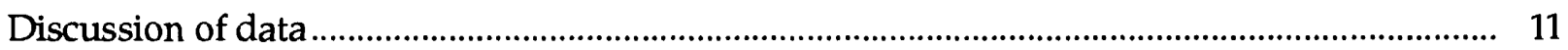

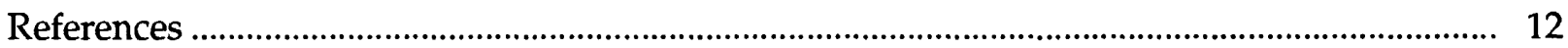

\section{FIGURES}

1. Map showing Rio Grande sampling sites............................................................................. 3

2. Schematic diagram of filter apparatus used for filtration of trace-element samples ........ $\quad 7$

3. Schematic diagram of nitric acid dispensing bottle ............................................................. 8 


\section{TABLES}

Page

1. Field blank data from the May-June 1994 sampling ............................................................ 14

2. Field blank data from the October 1994 sampling ............................................................. 15

3. Standard reference materials used in the determination of accuracy during the May-June 1994 sampling .................................................................................................. 16

4. Standard reference materials used in the determination of accuracy during the October 1994 sampling.................................................................................................... 23

5. Standard reference material NIST Buffalo River sediment used in the determination of accuracy for suspended sediments for the May-June and October 1994 samplings 31

6. Spiked recovery data for samples collected during the May-June 1994 sampling. 32

7. Spiked recovery data for samples collected during the October 1994 sampling 35

8. Water-quality properties and dissolved constituents in the Rio Grande in the vicinity of Albuquerque, N. Mex., May-June 1994 38

9. Water-quality properties and dissolved constituents in the Rio Grande in the vicinity of Albuquerque, N. Mex., October 1994

10. Trace-element concentrations in suspended sediment in the Rio Grande in the vicinity of Albuquerque, N. Mex., May and October 1994.

11. Total recoverable concentrations of selected constituents in the Rio Grande in the vicinity of Albuquerque, N. Mex., May and October 1994

12. Minimum reporting limits for selected dissolved trace elements used in this study and those previously reported by the U.S. Geological Survey 


\section{CONVERSION FACTORS AND VERTICAL DATUM}

Multiply

inch

foot

mile

cubic foot per second

ton
By

25.40

0.3048

1.609

0.02832

0.9072
To obtain

millimeter

meter

kilometer

cubic meter per second

metric ton

Temperatures in degrees Celsius $\left({ }^{\circ} \mathrm{C}\right)$ and degrees Fahrenheit $\left({ }^{\circ} \mathrm{F}\right)$ can be converted by the equations:

$$
\begin{gathered}
{ }^{\circ} \mathrm{F}=9 / 5\left({ }^{\circ} \mathrm{C}\right)+32 \\
{ }^{\circ} \mathrm{C}=\left({ }^{\circ} \mathrm{F}-32\right) / 1.8
\end{gathered}
$$

Sea level: In this report "sea level" refers to the National Geodetic Vertical Datum of 1929-a geodetic datum derived from a general adjustment of the first-order level nets of the United States and Canada, formerly called Sea Level Datum of 1929.

Use of brand names in this report is for identification purposes only and does not constitute endorsement by the U.S. Geological Survey. 


\title{
CONCENTRATIONS AND LOADS OF SELECTED TRACE ELEMENTS AND OTHER CONSTITUENTS IN THE RIO GRANDE IN THE VICINITY OF ALBUQUERQUE, NEW MEXICO, 1994
}

\author{
By Todd Kelly and H.E. Taylor
}

\begin{abstract}
The Pueblo of Isleta and the New Mexico Environment Department have established water-quality standards for the Rio Grande, which flows through Albuquerque, New Mexico. Trace-element concentrations historically have been greater than maximum permissible concentrations allowed by these standards. It is not known if these concentrations are due to sources from the Albuquerque metropolitan area or are from natural or other sources outside Albuquerque.

Accurate water-quality data with lower reporting limits than have been previously available were collected, and instantaneous concentrations and loads were calculated for trace elements and other constituents in the Rio Grande during high-flow and low-flow conditions. Seven sampling sites were selected upstream from, in, and downstream from metropclitan Albuquerque. Concurrent streamflow measurements were made at the time of sampling to determine suspended-sediment loads. Samples were analyzed separately for trace elenents dissolved in water (less than 0.4 micrometer in diameter) and for those contained in suspended sediment (greater than 0.1 micrometer in diameter). Sample collection and processing, analytical methods, and quality control are discussed.
\end{abstract}




\section{INTRODUCTION}

The Rio Grande flows southwardly through the west side of metropolitan Alk rquerque and receives effluent from storm-water drains, riverside irrigation drainage canals, and wastewater treatment plants. The Pueblo of Isleta Indian Reservation, located downstream from Albuquerque, and the New Mexico Environment Department have established water-quality standards, including those for trace elements, for the Rio Grande. Historical concent-ations of some constituents in the Rio Grande, such as aluminum, arsenic, selenium, and silver, have been greater than maximum permissible concentrations allowed by these water-quality standards. Natural sources of trace elements are known upstream from Albuquerque, such as ars onic from the Jemez Mountains, but their respective contributions to the Rio Grande have not been accurately quantified. It is not known, therefore, to what extent concentrations of trace elements in the reach of the Rio Grande flowing through Albuquerque are due to sources from the Albuquerque metropolitan area or due to natural or other sources outside the area. This uncertainty is due in part to current standard sampling and laboratory methods that may not produce sufficiently accurate data, particularly at lower concentrations, to discern small differences in concentrations among sampling sites on the river.

The objective of the study was to obtain accurate water-quality data with lower reporting limits for selected dissolved trace elements than previously available and to calculate instantaneous loads of selected trace elements and other constituents in the Rio Grande during steady high-flow and steady low-flow conditions. Water-quality data were collecte $d$ at sites upstream from metropolitan Albuquerque, in the metropolitan area, and downstriam from Albuquerque. These data will allow water-quality managers and regulators to better compare water-quality conditions among sampling sites on the river and help to determine sources of high constituent concentrations. The report was prepared in cooperation with the City of Albuquerque Public Works Department.

\section{Purpose and Scope}

This report presents water-quality data collected for this study and calculations of instantaneous concentrations and loads. Water samples were collected at seven sites (fig. 1) during high flow (May 31-June 2, 1994) and low flow (October 3-6, 1994). Samples were analyzed separately for trace elements dissolved in water (less than 0.4 micrometer in diameter) and for: those contained in suspended sediment (greater than 0.1 micrometer in diameter). Streamflow measurements were made at the time of sampling, and companion suspended-sedimert samples were collected to determine sediment concentrations and percentages of sand and finer particles. Specific conductance, $\mathrm{pH}$, stream temperature, dissolved oxygen, and alkalinity also were measured at the time of sampling. 


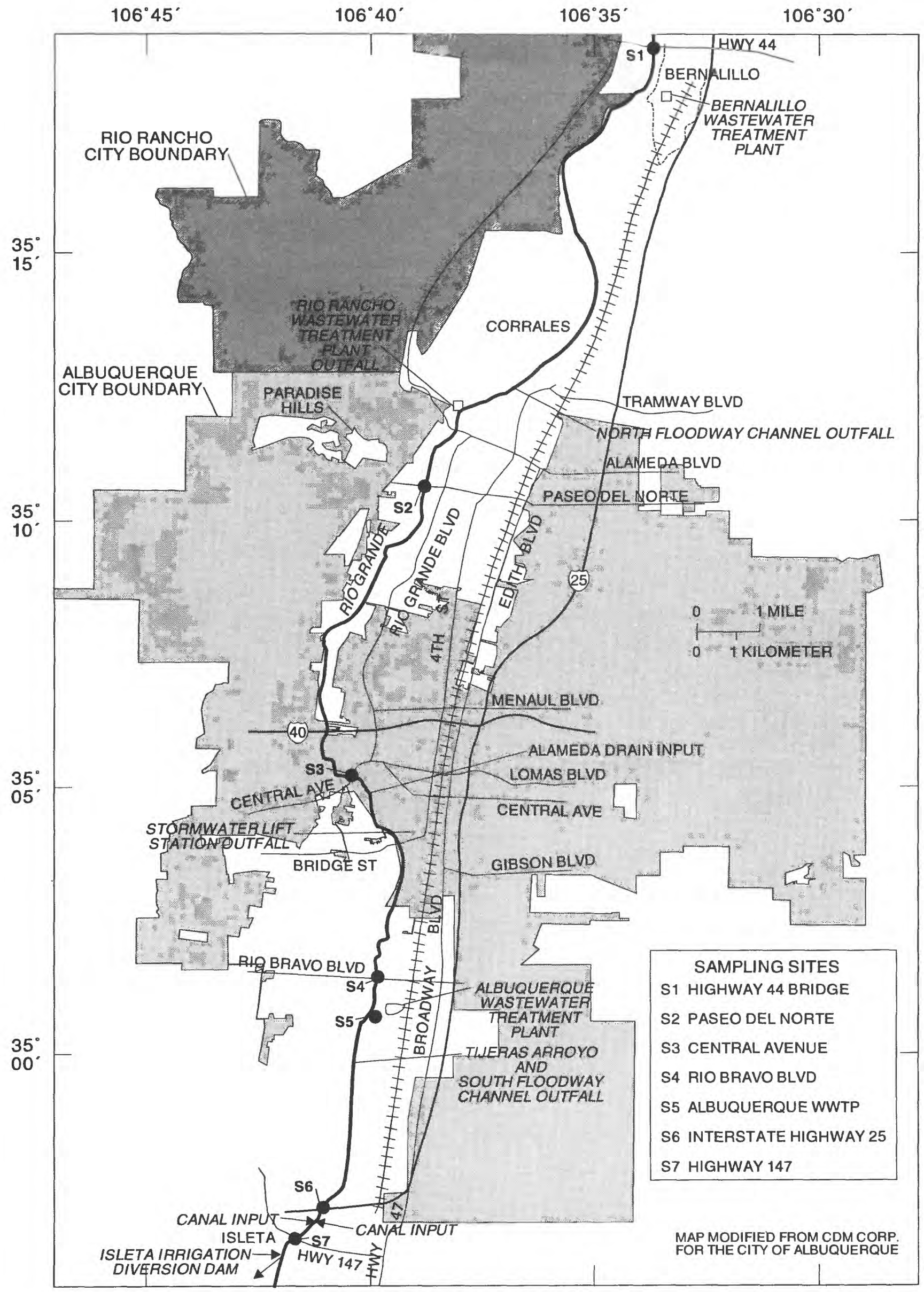

Figure 1.--Rio Grande sampling sites. 


\section{Description of Sampling Sites}

Water samples were collected at seven sites. Location of the sites is shown in figure 1 . The sites selected for the sampling are:

S1. State Highway 44 Bridge near Bernalillo (station 351921106332710)

Site $\mathrm{S} 1$ is in the Rio Grande immediately downstream from the Jemez River, which is known to contain relatively high, natural concentrations of certain trace elements such as arsenic, and upstream from metropolitan Albuquerque. It serves as a reference site for conditions upstream from Albuquerque.

S2. Paseo del Norte Bridge (station 08329928)

Site S2 is in the Rio Grande downstream from discharges from the Bernalillo wastewater treatment plant (WWTP), Rio Rancho WWTP, and the Albuquerque North Floodway Diversion Channel, which drains storm-water runoff from much of Albuquerque.

S3. Central Avenue Bridge (station 08330000)

Site S3 is in the Rio Grande about in the middle of the west side of metropolitan Albuquerque and downstream from inflows from the riverside drainage canals and storm-water pumping stations.

S4. Rio Bravo Boulevard Bridge (station 08330150)

Site S4 is in the Rio Grande downstream from discharges from downtown Albuquerque's storm sewers and approximately 0.7 mile upstream from the discharge to the Rio Grande from the Albuquerque WWTP.

S5. Albuquerque WWTP effluent channel (station 350104106401110)

Site S5 is in the effluent channel for Albuquerque's treated wastewater, which discharges to the river about 300 feet west of the sampling site.

S6. Interstate Highway 25 Bridge (station 345705106405210 )

Site $\mathbf{S 6}$ is in the Rio Grande downstream from discharges from the Albuquerque WWTP, Tijeras Arroyo, and the South Floodway Diversion Channel. Tijeras Arroyo and the South Floodway Diversion Channel normally are dry and flow only after large rainstorms or snowmelt. The site represents Rio Grande inflow to the Pueblo of Isleta.

S7. State Highway 147 immediately upstream from the Isleta Irrigation Diversion Dam (station 08331000)

Site S7 is in the Rio Grande downstream from the confluence of riverside drains on the east and west banks of the Rio Grande and downstream from all point and non-point discharges from and adjacent to metropolitan Albuquerque.

\section{Acknowledgments}

Ron Antweiler, Dale Peart, Dave Roth, and Terry Brinton from H.E. Taylor's staff and George Sieber from the U.S. Geological Survey (USGS) Albuquerque Field Headquarters assisted in making field measurements, and collecting, processing, and analyzing samples. Kim Ong of the USGS New Mexico District Office provided technical review of field collection and analytical results. 


\section{METHODOLOGY}

\section{Sample Collection}

During high flow, a modification of a previously described collapsible-bag sampler (Stevens and others, 1980; Nordin and others, 1983; Meade, 1985) was used to collect depthintegrated samples at three to five verticals from bridges at each sampling site (Moody and Meade, 1992). The equipment consisted of a USGS D-77 sampler (Horowitz and others, 1994) modified to hold a perforated 3-liter polyethylene bottle and a Teflon-bag liner. All verticals at each site were combined into a composite sample. Approximately 20 liters of total composited sample was collected at each site. Teflon bags used in the bag sampler minimized sample contamination and facilitated quantitative transfer of sample and suspended material. Possible metal contamination of the sample was minimized by using Teflon (polytetrafluoroethylene), high-density polyethylene, or Teflon-coated stainless steel sample processing equipment. Talcfree polyethylene, polyvinyl chloride, or Teflon gloves were used during the entire sample handling and processing procedure. At low flow, a modified Teflon USGS DH-81 hand-held sampler (Horowitz and others, 1994) was used to collect depth-integrated samples. A replaceable Teflon-bag liner (changed from site to site) in this sampler minimized crosscontamination between sampling sites. A minimum of 10 equally spaced verticals were composited into a 20-liter Teflon-coated churn.

\section{Sample Processing}

During compositing, samples were passed through a precleaned nylon 63-micron screen to remove sand-size suspended material and miscellaneous debris. Field blanks using deionized water indicate that the nylon screen contributed negligible contamination to trace-element concentrations. The composited samples, composed of water and particulate matter (smaller than 63 microns), were representatively split into subsamples using a Teflon-coated stainless steel churn splitter. Individual aliquots were taken from the splitter for analysis of trace elements, including mercury ( $\mathrm{Hg}$ ); major anions; dissolved organic carbon (DOC), and nutrients.

A Teflon vacuum filter apparatus (similar to the one shown in fig. 2) was used to remove particulate matter greater than 0.40 micrometer in diameter from the trace-element subsample. The following protocol was used for the filtration: (1) The filter funnel was thoroughly cleaned and rinsed with deionized water. (2) A new 0.40-micrometer-pore-size, 47-millimeter-diameter Nuclepore polycarbonate-membrane filter was placed on the filter support and precleaned by drawing approximately 20 milliliters of 0.1 -percent (volume/volume) ultrapure nitric acid rinse solution through the filter into a waste bottle. (3) The filter was then rinsed by drawing approximately 50 milliliters of deionized water through it into a waste bottle. (4) About 20 milliliters of the shaken, composited subsample was then filtered to prerinse the sample bottle and also effectively "preload" the filter with particulate. (5) The balance of the subsample (about 225 milliliters) was filtered into the sample bottle. (6) Finally, the filtered sample was preserved with the addition of 2 milliliters of concentrated ultrapure nitric acid using a Teflon dispensing bottle as shown in figure 3 (Brinton and others, 1995). By squeezing the sides of this bottle, high purity nitric acid is forced up the Teflon tubing, filling the holding well. The volume of this well is changed by adjustment of the height of the Teflon plug. Excess acid returns to the bottom of the bottle when the well overflows. The Teflon cap is removed and the precise volume of acid in the well is dispensed by inverting the bottle. Only one filter membrane was used for the entire 
aliquot. The filter apparatus was thoroughly cleaned and rinsed between samples to minimize trace-element contamination.

The 125-milliliter mercury subsample was filtered into a precleaned clear glass bottle, following the protocol outlined above for the trace-element subsample. It was subsequently preserved with 5 milliliters of a 1-percent potassium dichromate solution in concentrated ultrapure nitric acid. The dichromate preservative was always added remotely from the sample processing area to minimize the risk of chromium contamination to other trace-element samples.

During the May-June 1994 sampling, the major anion subsamples were filtered through a 0.45-micrometer-pore-size, 25-millimeter-diameter polysulfone-membrane syringe filter. During the October 1994 sampling, this subsample was filtered through a 0.45-micrometer-pore-size, 47millimeter-diameter polysulfone-membrane filter in a polycarbonate filtration funnel. For both samplings, these subsamples were immediately chilled to approximately $4{ }^{\circ} \mathrm{C}$ and transported to the National Research Program (NRP) laboratory in Boulder, Colorado, for analysis.

Separate DOC and nutrient samples were split and processed by pressure filtration through a 47 -millimeter, 0.45 -micrometer silver membrane filter using nitrogen gas in a stainless steel pressure filtration apparatus. Prior to filtering the sample, the filter was thoroughly rinsed with deionized water. The DOC sample was filtered into a precleaned amber glass bottle and chilled prior to transport to the laboratory for analysis. The nutrient sample was filtered directly into an opaque polyethylene bottle, which was immediately chilled after filtration.

The remaining portion of the composited sample was processed through a tangential-flow ultrafilter (Millipore MiniTan) to remove particulates larger than 0.1 micrometer in diameter. The separated particulate fractions from the ultrafilter were retained for characterization and chemical analysis. The membranes used in the ultrafilter were made of deacetylated cellulose. Trace-element adsorption studies by Leenheer and others (1989) have determined that no significant adsorption occurs on this membrane material. The ultrafilter system was prepared for sample collection according to the following protocol: (1) Prior to sample processing, the ultrafilter system was dismantled and each component was individually cleaned with deionized water. (2) The system was reassembled and 2 liters of 0.1-percent (volume/volume) ultrapure nitric acid was recirculated for approximately 15 minutes to remove any metals from the filter plates. (3) A minimum of 20 liters of deionized water was pumped through the system to rinse out the dilute nitric acid. (4) The sample was then pumped through the system. A stack of eight precleaned filter plates was typically used for each sample to provide suitable processing times and to eliminate carryover contamination between samples. 


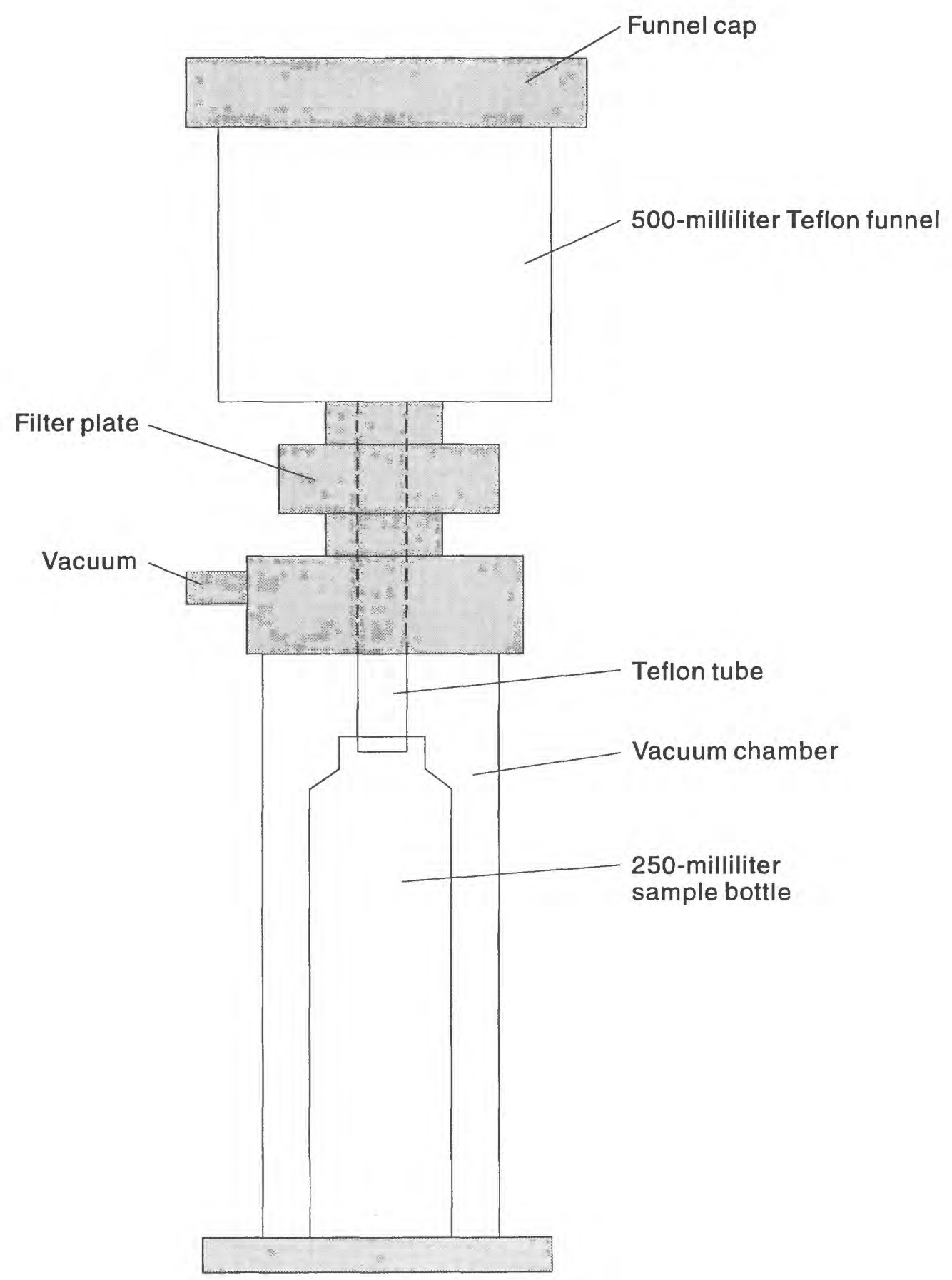

Figure 2.--Schematic diagram of filter apparatus used for filtration of trace-element samples. 


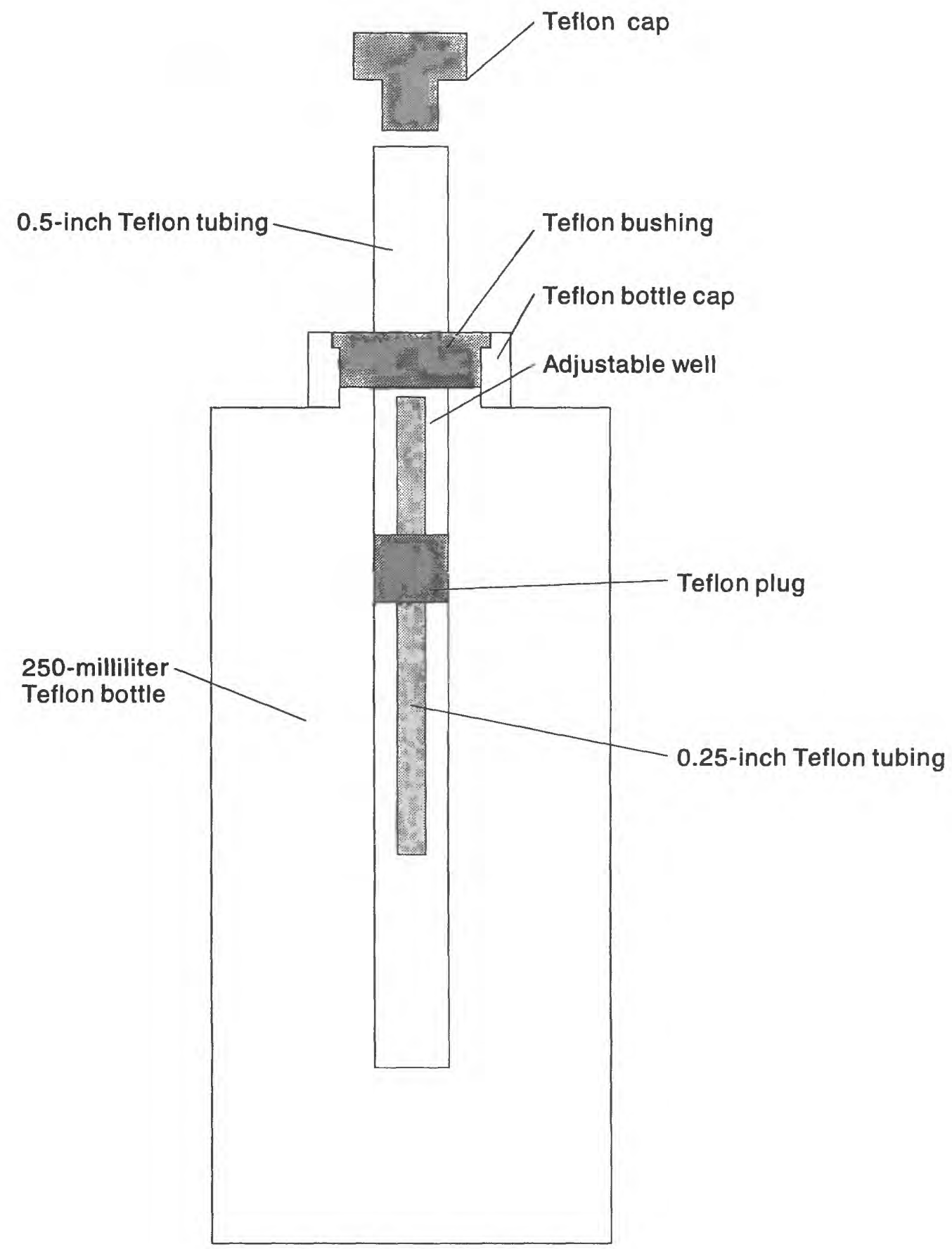

Figure 3.--Schematic diagram of nitric acid dispensing bottle. 


\section{Analytical Methods}

Trace elements were determined by a combination of analytical techniques including inductively coupled plasma atomic emission spectrometry (ICP-AES) and flame atcmic absorption spectrometry (F-AAS). A Perkin Elmer-Science Model 5000 inductively coupled plasma-mass spectrometer (ICP-MS) was configured and optimized for trace-element analysis as previously described (Taylor and Garbarino, 1991; Garbarino and Taylor, 1992). Individual trace elements were quantitatively analyzed with appropriate interference corrections for the following analytes: silver ( $\mathrm{Ag}$ ), aluminum ( $\mathrm{Al})$, arsenic (As), boron (B), barium (Ba), beryllium $(\mathrm{Be})$, cadmium $(\mathrm{Cd})$, cobalt $(\mathrm{Co})$, chromium $(\mathrm{Cr})$, copper $(\mathrm{Cu})$, lithium $(\mathrm{Li})$, manganese $(\mathrm{I} / \mathrm{n})$, molybdenum (Mo), nickel (Ni), lead (Pb), selenium (Se), strontium ( $\mathrm{Sr}$ ), thallium (Tl), uranium (U), vanadium (V), and zinc ( $\mathrm{Zn})$. A complete description of the analytical method and method accuracy and precision data is provided by Garbarino and Taylor (1992). Selenium concentrations were determined by a flow injection-hydride generation ICP-MS procedure (Stroh and others, 1993).

Other constituents were determined using a Jarrell-Ash Atomcomp 975 inductively coupled argon plasma-atomic emission spectrometer. The analytical system, methodology, detection limits, and accuracy and precision data for this method were described by Garba-ino and Taylor (1979; 1980) and Skougstad and others (1979). Analytes determined by this method were iron $(\mathrm{Fe})$, calcium $(\mathrm{Ca})$, magnesium $(\mathrm{Mg})$, sodium $(\mathrm{Na})$, and silica $\left(\mathrm{SiO}_{2}\right)$. Potassium $(\mathrm{K})$ was determined by flame-atomic absorption spectrometry (F-AAS) using a Varian Model AA-975 instrument; the method was described by Skougstad and others (1979).

Major anion concentrations of chloride $(\mathrm{Cl})$ and sulfate $\left(\mathrm{SO}_{4}\right)$ and trace-concentration-level fluoride $(\mathrm{F})$ and bromide $(\mathrm{Br})$, which are used to describe general water chemistry, were determined by ion chromatographic techniques (Hedley and Fishman, 1982; T.I. Brinton, R.C. Antweiler, and H.E. Taylor, U.S. Geological Survey, written commun., 1992). Alkalinity was determined using an automated Radiometer titrator and calculated from $\mathrm{pH}$ data (Skougstad and others, 1979). DOC was determined by infrared absorption spectrometric methodology (Menzel and Vaccaro, 1964).

Nutrient species including the ions ammonium $\left(\mathrm{NH}_{4}{ }^{+}\right)$, nitrite $\left(\mathrm{NO}_{2}{ }^{-}\right)$, nitrate $\left(\mathrm{NO}_{3}{ }^{-}\right)$, and orthophosphate $\left(\mathrm{PO}_{4}{ }^{3-}\right)$ were determined with an Alpchem autoanalyzer (spectrophotometric determination) using methodologies previously reported by Antweiler and others (15.3). Ultratrace-concentration-level mercury was determined by a cold vapor atomic fluorescence spectrometric methodology described by Roth (1994). Companion samples were submitted to the USGS National Water Quality Laboratory (NWQL) in Arvada, Colorado, for stancard analysis of cyanide $\left(\mathrm{CN}^{-}\right)$in the filtered water and the filtered suspended-sediment samples. The USGS Albuquerque Field Headquarters laboratory analyzed companion samples for suspendedsediment dry-weight concentrations and for dry-weight percentages of sand and fine particles using standard techniques. 


\section{Quality Control}

The quality of the analytical results was controlled by collecting numerous field blanks and analyzing certified reference standards extensively along with analysis of the samples and the measurement of recoveries from artificially spiked samples. Field blanks were used to identify possible sources of contamination to samples during their collection and processing. The accuracy of the analysis and the performance of laboratory instrumentation were monitored using reference standards. Spike recoveries were used to estimate the probability of interelement interferences during analysis.

A series of field blanks was collected by processing about 20 liters of specially prepared NRP laboratory-deionized water through the entire sample collection, subsampl'ng, and following all sample processing procedures in an effort to identify possible sources cf sample contamination. NRP laboratory-deionized water is processed using a multi-stage reverse osmosis procedure. The subsequent product tests below reporting limits for all analytes. Aliquots were taken at various steps through the entire procedure when procersing the deionized water. Samples collected for trace-element, major anion, DOC, and nutrient analyses represented water processed through the bag sampler using Teflon bags, 20-liter Teflon-coated churn splitters (designated churn A in table 1 (all tables are in the back of the report) and churn A2 in table 2), and Teflon holding bottles (designated as bottles A, F, and $\mathrm{H}$ in table 1 ard bottles 2,4 , and $\mathrm{H}$ in table 2). Deionized water was also filtered through a Nuclepore filter tc obtain a process (filter) blank. All field blank samples were preserved following the same prctocols as their corresponding sample types. Results for the constituents in the field blanks for the two sampling trips, shown in tables 1 and 2, demonstrate negligible contamination for $\mathrm{Ag}, \mathrm{Al}, \mathrm{As}$, $\mathrm{Ca}, \mathrm{Cr}, \mathrm{K}, \mathrm{Mn}, \mathrm{Ni}, \mathrm{PO}_{4}, \mathrm{Zn}$, and $\mathrm{DOC}$.

The accuracy of the sample data was ensured by analyzing one to seven standard reference materials periodically, within a set of unknown samples. Reference standards routinely composed about 30 percent of an analytical run. Data for each of the reference standards used for quality assurance during each sampling are listed in tables 3-5. The average and standard deviations are based on the sample population given and represent the accuracy and precision throughout the analysis of the entire set of samples. The measured values usually were within 10 percent of the standard reference material certified values. Exceptions were for $\mathbf{A g}, \mathrm{Al}, \mathrm{B}, \mathrm{Cd}$, $\mathrm{Co}, \mathrm{Cr}, \mathrm{V}, \mathrm{Zn}$, and $\mathrm{NH}_{4}$, which often were outside 10 percent of the standard reference material certified values but usually within 20 percent of the certified values.

Tables 6 and 7 list analyte recovery information for samples for the trace elements As, Be, $\mathrm{Cd}, \mathrm{Cr}, \mathrm{Cu}, \mathrm{Hg}, \mathrm{Ni}, \mathrm{Pb}, \mathrm{U}$, and $\mathrm{Zn}$, which were spiked in the field prior to transpcrt to the laboratory. Analyte recoveries generally ranged from 90 to 110 percent. 


\section{DISCUSSION OF DATA}

Loads in table 8-11 are reported in tons per day with the assumption that the instantaneous streamflow and concentration of each constituent at the time of sampling are representativo of mean daily values. Sampling was completed during steady-state flow conditions; however, some fluctuation in flow, sediment concentration, and trace-element concentration was inevitable and is considered to be small. Table 8 summarizes dissolved-constituent concentrations for the MayJune sampling, and table 9 summarizes those for the October 1994 sampling. Table 10 summarizes trace-element concentrations in suspended sediment which were analyzed using a "total digestion" method, whereby suspended sediments are totally dissolved, as well as any adsorbed ions and constituents, before the trace-element concentration is analyzed. Table 11 lists whole-water analyses of samples collected from three selected sampling sites during the highflow and low-flow samplings. Whole-water analyses represent total recoverable ions, which are those readily leached from suspended sediments by a dilute hydrochloric acid solution, plus any dissolved ions in the water. Complete dissolution of all particulate matter is not achieved by the total recoverable method and thus represents 95 percent or less of "total digestion."

Minimum reporting limits for selected dissolved trace elements used in this study and those previously reported by the USGS are shown in table 12. The NWQL defines minimum reporting limit (MRL) as the smallest concentration of an analyte that may be reliably reported using a given analytical method (Timme, 1995). The MRL is not as well defined statistically and is generally greater than an MDL for a given analytical method. A maximum detection l:mit (MDL), as reported by the NWQL, is the minimum concentration at which a compound can be identified, measured, and reported with 99-percent confidence that the compound concentration is greater than zero (Timme, 1995). Even with the lower reporting limits available for this stidy, some trace-element concentrations remained below reporting limits. Be, $\mathrm{Cd}$, and $\mathrm{Cr}$ (except at the WWTP effluent channel) concentrations were below detection limits during the high-flow sampling. $\mathrm{Ag}$ (except at the WWTP effluent channel), Be, Cd, Co (except at three upstream sites), and $\mathrm{Fe}$ (except at the WWTP effluent channel) concentrations were below detection limits during the low-flow sampling. $\mathrm{CN}$ concentration during both sampling periods was below the detection limit of 0.01 milligram per liter.

In general, dissolved trace-element concentrations were much higher in effluent from the Albuquerque WWTP than in the Rio Grande; however, both sampling sites downstream f"om the effluent channel showed no significant increase in dissolved trace-element concentrations during the high-flow sampling. Slight increases in concentrations of $\mathrm{As}, \mathrm{B}, \mathrm{Mo}, \mathrm{Pb}, \mathrm{Sr}$, ard V were detected at the two sampling sites downstream from the WWTP, but all were well within the State of New Mexico water-quality standards for either domestic or livestock water supply (New Mexico Water Quality Control Commission, 1995). State water-quality standards for B, Mo, $\mathrm{Sr}$, and $\mathrm{V}$ have not been established for domestic water supplies. Generally, dissolved concentrations of trace elements showed a more marked increase downstream from Berna lillo (site S1) to Isleta (site S7) during the low-flow sampling; however, all were still well below State water-quality standards for waters designated as domestic or livestock supply. 


\section{REFERENCES}

Antweiler, R.C., Patton, C.J., and Taylor, H.E., 1993, Automated colorimetric methods for determination of nitrite plus nitrate, ammonium, and orthophosphate ions in natural water samples: U.S. Geological Survey Open-File Report 93-638, 40 p.

Brinton, T.I., Garbarino, J.R., Peart, D.B., Taylor, H.E., and Antweiler, R.C., 1995, Conc ntration and transport data for dissolved inorganic constituents in water collected during seven cruises on the Mississippi River and some of its tributaries, July 1987-June 1990: U.S. Geological Survey Open-File Report 94-524, $102 \mathrm{p}$.

Garbarino, J.R., and Taylor, H.E., 1979, An inductive-coupled plasma atomic-emission spectrometric method for routine water quality testing: Applied Spectroscopy, v. 33, p. 220226.

1980, A Babingtion-type nebulizer for the use in the analysis of natural water samples by inductively coupled plasma spectrometry: Applied Spectroscopy, v. 34, p. 393-399.

1992, Inductively coupled plasma-mass spectrometric method for the determination of dissolved trace elements in water: U.S. Geological Survey Open-File Report 94-359, 92 p.

Hedley, A.G., and Fishman, M.J., 1982, Automation of an ion chromatograph for preripitation analysis with computerization data reduction: U.S. Geological Survey Water-Fresources Investigations $81-78,38 \mathrm{p}$.

Horowitz, A.J., Demas, C.R., Fitzgerald, K.K., Miller, T.L., and Rickert, D.A., 1994, U.S. Geological Survey protocol for the collection and processing of surface-water samples for the subsequent determination of inorganic constituents in filtered water: U.S. Geological Survey Open-File Report 94-539, $57 \mathrm{p}$.

Leenheer, J.A., Meade, R.H., Taylor, H.E., and Pereira, W.E., 1989, Sampling, fractionation, and dewatering of suspended sediment from the Mississippi River for geochemical and trace contaminant analysis, in Mallard, G.E., ed., U.S. Geological Survey Toxic Substances Hydrology Program--Proceedings of the technical meeting, Phoenix, Ariz., September 2630, 1988: U.S. Geological Survey Water-Resources Investigations Report 88-4220, p. 501-511.

Meade, R.H., 1985, Suspended sediment in the Amazon River and its tributaries in Brazil during 1982-84: U.S. Geological Survey Open-File Report 85-492, 34 p.

Menzel, D.W., and Vaccaro, R.F., 1964, The measurement of dissolved organic and particulate carbon in seawater: Limnology and Oceanography, v. 9, p. 138-142.

Moody, J.A., and Meade, R.H., 1992, Hydrologic and sedimentologic data collected during three cruises at low water on the Mississippi River and some of its tributaries, July 1987-June 1988: U.S. Geological Survey Open-File Report 91-485, 143 p.

New Mexico Water Quality Control Commission, 1995, Water-quality standards for interstate and intrastate streams in New Mexico: Santa $\mathrm{Fe}, 49 \mathrm{p}$.

Nordin, C.F., Jr., Cranston, C.C., and Mejia, B.A., 1983, New technology for measuring water and suspended-sediment discharge of large rivers, in Proceedings of the International Symposium on River Sedimentation, 2d, Nanjing, China, October 11-16, 1983: Beijirg, Water Resources and Electric Power Press, theme E, paper E20, p. 1145-1158.

Roth, D.A., 1994, Ultratrace analysis of mercury and its distribution in some natural waters in the United States: Fort Collins, Colorado State University, Ph.D. dissertation, 309 p. 


\section{REFERENCES-Concluded}

Skougstad, M.W., Fishman, M.J., Friedman, L.C., Erdman, D.E., and Duncan, S.S., 1979, Methods for the determination of inorganic substances in water and fluvial sediments: U.S. Geological Survey Techniques of Water-Resources Investigations, book 5, chap. A1, p. 229.

Stevens, H.H., Jr., Lutz, G.A., and Hubbell, D.W., 1980, Collapsible-bag suspended-sediment sampler: American Society of Civil Engineers Proceedings, Hydraulic Division Journal, v. 166, no. HY4, p. 611-616.

Stroh, A., Denoyer, E.R., Lu, Q., and Vollkopf, U., 1993, Optimization and use of flow inje-tion vapor generation for ICP-MS: Perkin Elmer Sciex App. Report FIAS FAR1, p. 1-24.

Taylor, H.E., and Garbarino, J.R., 1991, The measurement of trace metals in water resource monitoring samples by inductively coupled plasma-mass spectrometry: Spectrochimica Acta Reviews, v. 14, p. 33-44.

Timme, P.J., 1995, National Water Quality Laboratory 1995 services catalog: U.S. Geolc rical Survey Open-File Report 95-353, 120 p. 
Table 1.--Field blank data from the May-June 1994 sampling

[ $\mu \mathrm{g} / \mathrm{L}$, micrograms per liter; $\mathrm{mg} / \mathrm{L}$, milligrams per liter; <, less than; na, not applicable]

\begin{tabular}{|c|c|c|c|c|c|c|c|c|}
\hline $\begin{array}{l}\text { Chemical } \\
\text { constituent } \\
\text { and unit } \\
\text { of meas- } \\
\text { urement }\end{array}$ & $\begin{array}{l}\text { Deionized } \\
\text { water }\end{array}$ & $\begin{array}{c}\text { Teflon } \\
\text { bag }\end{array}$ & $\begin{array}{c}\text { Churn } \\
\text { A }\end{array}$ & $\begin{array}{l}\text { Holding } \\
\text { bottle A }\end{array}$ & $\begin{array}{l}\text { Holding } \\
\text { bottle F }\end{array}$ & $\begin{array}{l}\text { Holding } \\
\text { bottle H }\end{array}$ & $\begin{array}{l}\text { Process } \\
\text { blank }^{1}\end{array}$ & $\begin{array}{c}\text { Ultra- } \\
\text { permeate }\end{array}$ \\
\hline $\mathrm{Ag}(\mu \mathrm{g} / \mathrm{L})$ & 0.08 & 0.07 & 0.08 & 0.07 & 0.08 & 0.07 & 0.08 & 0.08 \\
\hline $\mathrm{Al}(\mu \mathrm{g} / \mathrm{L})$ & 0.6 & $<0.1$ & 2.1 & 1.7 & $<0.1$ & 0.1 & 0.5 & 1.6 \\
\hline As $(\mu \mathrm{g} / \mathrm{L})$ & 0.07 & 0.07 & 0.07 & 0.07 & 0.07 & 0.07 & 0.07 & 0.08 \\
\hline$B(\mu \mathrm{g} / \mathrm{L})$ & $<0.4$ & $<0.4$ & $<0.4$ & $<0.4$ & $<0.4$ & $<0.4$ & $<0.4$ & $<0.4$ \\
\hline $\mathrm{Ba}(\mu \mathrm{g} / \mathrm{L})$ & $<0.02$ & $<0.02$ & $<0.02$ & $<0.02$ & $<0.02$ & $<0.02$ & $<0.02$ & $<0.02$ \\
\hline $\mathrm{Be}(\mu \mathrm{g} / \mathrm{L})$ & $<0.02$ & $<0.02$ & $<0.02$ & $<0.02$ & $<0.02$ & $<0.02$ & $<0.02$ & $<0.02$ \\
\hline $\mathrm{Br}(\mathrm{mg} / \mathrm{L})$ & $<0.02$ & $<0.02$ & $<0.02$ & $<0.02$ & $<0.02$ & $<0.02$ & $<0.02$ & na \\
\hline $\mathrm{Ca}(\mathrm{mg} / \mathrm{L})$ & $<0.007$ & $<0.007$ & 0.010 & 0.024 & $<0.007$ & $<0.007$ & 0.015 & $<0.007$ \\
\hline $\mathrm{Cd}(\mu \mathrm{g} / \mathrm{L})$ & $<0.02$ & $<0.02$ & $<0.02$ & $<0.02$ & $<0.02$ & $<0.02$ & $<0.02$ & $<0.02$ \\
\hline $\mathrm{Cl}(\mathrm{mg} / \mathrm{L})$ & $<0.05$ & $<0.05$ & $<0.05$ & $<0.05$ & $<0.05$ & $<0.05$ & $<0.05$ & na \\
\hline Co $(\mu g / L)$ & $<0.01$ & $<0.01$ & $<0.01$ & $<0.01$ & $<0.01$ & $<0.01$ & $<0.01$ & $<0.01$ \\
\hline $\mathrm{Cr}(\mu \mathrm{g} / \mathrm{L})$ & $<0.4$ & 0.4 & 0.4 & $<0.4$ & $<0.4$ & $<0.4$ & 0.4 & $<0.4$ \\
\hline $\mathrm{Cu}(\mu \mathrm{g} / \mathrm{L})$ & $<0.02$ & 0.05 & 0.11 & 0.07 & 0.06 & 0.08 & $<0.02$ & 0.20 \\
\hline $\mathrm{DOC}(\mathrm{mg} / \mathrm{L})$ & 0.18 & 0.18 & 0.11 & 0.31 & 0.49 & 0.25 & 0.39 & na \\
\hline $\mathrm{F}(\mathrm{mg} / \mathrm{L})$ & $<0.05$ & $<0.05$ & $<0.05$ & $<0.05$ & $<0.05$ & $<0.05$ & $<0.05$ & na \\
\hline $\mathrm{Fe}(\mathrm{mg} / \mathrm{L})$ & 0.008 & $<0.006$ & $<0.006$ & 0.007 & $<0.006$ & 0.007 & $<0.006$ & $<0.006$ \\
\hline $\mathrm{Hg}(\mu \mathrm{g} / \mathrm{L})$ & $<0.0004$ & $<0.0004$ & $<0.0004$ & 0.0005 & $<0.0004$ & $<0.0004$ & $<0.0004$ & na \\
\hline $\mathrm{Li}(\mu \mathrm{g} / \mathrm{L})$ & $<0.03$ & $<0.03$ & $<0.03$ & $<0.03$ & $<0.03$ & $<0.03$ & $<0.03$ & $<0.03$ \\
\hline $\mathrm{Mg}(\mathrm{mg} / \mathrm{L})$ & $<0.007$ & 0.021 & $<0.007$ & $<0.007$ & $<0.007$ & 0.017 & $<0.007$ & $<0.007$ \\
\hline $\mathrm{Mn}(\mu \mathrm{g} / \mathrm{L})$ & 0.08 & 0.08 & 0.14 & 0.15 & 0.09 & 0.09 & 0.13 & 0.11 \\
\hline Mo $(\mu \mathrm{g} / \mathrm{L})$ & $<0.01$ & $<0.01$ & $<0.01$ & $<0.01$ & $<0.01$ & $<0.01$ & $<0.01$ & $<0.01$ \\
\hline $\mathrm{NH}_{4}$ as $\mathrm{N}(\mathrm{mg} / \mathrm{L})$ & L) $<0.006$ & $<0.006$ & $<0.006$ & $<0.006$ & $<0.006$ & $<0.006$ & $<0.006$ & na \\
\hline $\mathrm{NO}_{2}$ as $\mathrm{N}(\mathrm{mg} / \mathrm{L})$ & L) $<0.002$ & $<0.002$ & $<0.002$ & $<0.002$ & $<0.002$ & $<0.002$ & $<0.002$ & na \\
\hline $\mathrm{NO}_{3}$ as $\mathrm{N}(\mathrm{mg} / \mathrm{L})$ & $<0.002$ & $<0.002$ & $<0.002$ & 0.005 & 0.022 & 0.006 & $<0.002$ & na \\
\hline $\mathrm{Na}(\mathrm{mg} / \mathrm{L})$ & $<0.01$ & $<0.01$ & $<0.01$ & 0.02 & $<0.01$ & $<0.01$ & $<0.01$ & $<0.01$ \\
\hline $\mathrm{Ni}(\mu \mathrm{g} / \mathrm{L})$ & $<0.02$ & 0.03 & 0.04 & 0.04 & $<0.02$ & 0.03 & 0.04 & 0.02 \\
\hline $\mathrm{PO}_{4}$ as $\mathrm{P}(\mathrm{mg} / \mathrm{L})$ & $<0.003$ & $<0.003$ & $<0.003$ & $<0.003$ & $<0.003$ & $<0.003$ & 0.003 & na \\
\hline $\mathrm{Pb}(\mu \mathrm{g} / \mathrm{L})$ & $<0.007$ & $<0.007$ & $<0.007$ & $<0.007$ & $<0.007$ & $<0.007$ & $<0.007$ & 0.055 \\
\hline $\mathrm{SO}_{4}(\mathrm{mg} / \mathrm{L})$ & $<0.5$ & $<0.5$ & $<0.5$ & $<0.5$ & $<0.5$ & $<0.5$ & $<0.5$ & na \\
\hline $\mathrm{SiO}_{2}(\mathrm{mg} / \mathrm{L})$ & $<0.3$ & $<0.3$ & $<0.3$ & $<0.3$ & $<0.3$ & $<0.3$ & $<0.3$ & $<0.3$ \\
\hline $\operatorname{Sr}(\mu \mathrm{g} / \mathrm{L})$ & $<0.004$ & $<0.004$ & $<0.004$ & $<0.004$ & $<0.004$ & $<0.004$ & $<0.004$ & $<0.004$ \\
\hline $\mathrm{Tl}(\mu \mathrm{g} / \mathrm{L})$ & $<0.004$ & $<0.004$ & $<0.004$ & $<0.004$ & $<0.004$ & $<0.004$ & $<0.004$ & $<0.004$ \\
\hline $\mathrm{U}(\mu \mathrm{g} / \mathrm{L})$ & $<0.003$ & $<0.003$ & $<0.003$ & $<0.003$ & $<0.003$ & $<0.003$ & $<0.003$ & $<0.003$ \\
\hline$V(\mu \mathrm{g} / \mathrm{L})$ & $<0.02$ & $<0.02$ & $<0.02$ & $<0.02$ & $<0.02$ & $<0.02$ & $<0.02$ & $<0.02$ \\
\hline $\mathrm{Zn}(\mu \mathrm{g} / \mathrm{L})$ & $<0.06$ & 0.29 & 0.40 & 0.30 & 0.24 & 0.25 & 0.13 & 0.21 \\
\hline
\end{tabular}

${ }^{1}$ Process blank is a blank that has been processed identically to field samples. 
Table 2.--Field blank data from the October 1994 sampling

$[\mu \mathrm{m}$, micrometer; $\mu \mathrm{g} / \mathrm{L}$, micrograms per liter; $\mathrm{mg} / \mathrm{L}$, milligrams per liter; <, less than; na, not applicable]

\begin{tabular}{|c|c|c|c|c|c|c|c|c|c|}
\hline $\begin{array}{l}\text { Chemical } \\
\text { constituent } \\
\text { and unit } \\
\text { of meas- } \\
\text { urement }\end{array}$ & $\begin{array}{l}\text { Deionized } \\
\text { water }\end{array}$ & $\begin{array}{c}\text { Teflon } \\
\text { bag }\end{array}$ & $\begin{array}{c}\text { Churn } \\
\text { A2 }\end{array}$ & $\begin{array}{l}\text { Holding } \\
\text { bottle } 2\end{array}$ & $\begin{array}{l}\text { Holding } \\
\text { bottle } 4\end{array}$ & $\begin{array}{l}\text { Holding } \\
\text { bottle H }\end{array}$ & $\begin{array}{l}\text { Process } \\
\text { blank }^{1}\end{array}$ & $\begin{array}{c}\text { Ultra- } \\
\text { permeate }\end{array}$ & $\begin{array}{c}0.1-\mu \mathrm{m} \\
\text { Nuclepore }\end{array}$ \\
\hline $\operatorname{Ag}(\mu \mathrm{g} / \mathrm{L})$ & $<0.01$ & $<0.01$ & $<0.01$ & $<0.01$ & $<0.01$ & $<0.01$ & $<0.01$ & 0.04 & $<0.01$ \\
\hline $\mathrm{Al}(\mu \mathrm{g} / \mathrm{L})$ & $<1.3$ & $<1.3$ & 2.8 & $<1.3$ & $<1.3$ & $<1.3$ & $<1.3$ & $<1.3$ & $<1.3$ \\
\hline As $(\mu \mathrm{g} / \mathrm{L})$ & $<0.02$ & $<0.02$ & $<0.02$ & $<0.02$ & $<0.02$ & $<0.02$ & $<0.02$ & $<0.02$ & $<0.02$ \\
\hline $\mathrm{B}(\mu \mathrm{g} / \mathrm{L})$ & $<0.6$ & $<0.6$ & $<0.6$ & $<0.6$ & $<0.6$ & $<0.6$ & $<0.6$ & $<0.6$ & $<0.6$ \\
\hline $\mathrm{Ba}(\mu \mathrm{g} / \mathrm{L})$ & $<0.2$ & $<0.2$ & $<0.2$ & $<0.2$ & $<0.2$ & $<0.2$ & $<0.2$ & $<0.2$ & $<0.2$ \\
\hline $\operatorname{Be}(\mu \mathrm{g} / \mathrm{L})$ & $<0.006$ & $<0.006$ & $<0.006$ & $<0.006$ & $<0.006$ & $<0.006$ & $<0.006$ & $<0.006$ & $<0.006$ \\
\hline $\mathrm{Br}(\mathrm{mg} / \mathrm{L})$ & $<0.02$ & $<0.02$ & $<0.02$ & $<0.02$ & $<0.02$ & $<0.02$ & $<0.02$ & $<0.02$ & na \\
\hline $\mathrm{Ca}(\mathrm{mg} / \mathrm{L})$ & $<0.007$ & $<0.007$ & 0.079 & 0.015 & 0.024 & 0.015 & 0.013 & $<0.007$ & 0.021 \\
\hline $\mathrm{Cd}(\mu \mathrm{g} / \mathrm{L})$ & $<0.01$ & $<0.01$ & $<0.01$ & $<0.01$ & $<0.01$ & $<0.01$ & $<0.01$ & $<0.01$ & $<0.01$ \\
\hline $\mathrm{Cl}(\mathrm{mg} / \mathrm{L})$ & $<0.05$ & $<0.05$ & $<0.05$ & $<0.05$ & $<0.05$ & $<0.05$ & $<0.05$ & $<0.05$ & na \\
\hline Co $(\mu \mathrm{g} / \mathrm{L})$ & $<0.01$ & 0.01 & $<0.01$ & $<0.01$ & $<0.01$ & $<0.01$ & $<0.01$ & $<0.01$ & $<0.01$ \\
\hline $\mathrm{Cr}(\mu \mathrm{g} / \mathrm{L})$ & $<0.06$ & 0.10 & $<0.06$ & $<0.06$ & $<0.06$ & $<0.06$ & 0.06 & 0.07 & $<0.06$ \\
\hline $\mathrm{Cu}(\mu \mathrm{g} / \mathrm{L})$ & $<0.05$ & $<0.05$ & $<0.05$ & $<0.05$ & $<0.05$ & $<0.05$ & $<0.05$ & $<0.05$ & $<0.05$ \\
\hline $\mathrm{DOC}(\mathrm{mg} / \mathrm{L})$ & 0.07 & 0.05 & 0.07 & 0.23 & 0.02 & 0.05 & 0.14 & 0.16 & na \\
\hline $\mathrm{F}(\mathrm{mg} / \mathrm{L})$ & $<0.05$ & $<0.05$ & $<0.05$ & $<0.05$ & $<0.05$ & $<0.05$ & $<0.05$ & $<0.05$ & na \\
\hline $\mathrm{Fe}(\mathrm{mg} / \mathrm{L})$ & $<0.006$ & $<0.006$ & $<0.006$ & $<0.006$ & $<0.006$ & $<0.006$ & $<0.006$ & $<0.006$ & $<0.006$ \\
\hline $\mathrm{Hg}(\mu \mathrm{g} / \mathrm{L})$ & 0.0006 & 0.0011 & 0.0012 & 0.0017 & 0.0008 & $<0.0004$ & 0.0010 & 0.0010 & na \\
\hline $\mathrm{K}(\mathrm{mg} / \mathrm{L})$ & 0.01 & 0.01 & 0.02 & 0.01 & 0.02 & 0.01 & 0.01 & 0.02 & 0.02 \\
\hline $\mathrm{Li}(\mu \mathrm{g} / \mathrm{L})$ & $<0.07$ & $<0.07$ & $<0.07$ & $<0.07$ & $<0.07$ & $<0.07$ & $<0.07$ & $<0.07$ & $<0.07$ \\
\hline $\mathrm{Mg}(\mathrm{mg} / \mathrm{L})$ & $<0.007$ & $<0.007$ & $<0.007$ & $<0.007$ & $<0.007$ & $<0.007$ & $<0.007$ & $<0.007$ & $<0.007$ \\
\hline $\operatorname{Mn}(\mu \mathrm{g} / \mathrm{L})$ & $<0.04$ & $<0.04$ & 0.40 & 0.05 & 0.04 & $<0.04$ & 0.07 & $<0.04$ & 0.05 \\
\hline $\operatorname{Mo}(\mu \mathrm{g} / \mathrm{L})$ & $<0.01$ & 0.01 & 0.01 & $<0.01$ & 0.01 & $<0.01$ & $<0.01$ & 0.02 & 0.01 \\
\hline $\mathrm{NH}_{4}$ as $\mathrm{N}(\mathrm{mg} / \mathrm{L}$ & L) $<0.005$ & $<0.005$ & $<0.005$ & 0.006 & $<0.005$ & 0.005 & $<0.005$ & $<0.005$ & na \\
\hline $\mathrm{NO}_{2}$ as $\mathrm{N}(\mathrm{mg} / \mathrm{L})$ & L) $<0.002$ & $<0.002$ & $<0.002$ & $<0.002$ & $<0.002$ & $<0.002$ & $<0.002$ & $<0.002$ & na \\
\hline $\mathrm{NO}_{3}$ as $\mathrm{N}(\mathrm{mg} / \mathrm{L})$ & L) $<0.005$ & $<0.005$ & $<0.005$ & 0.045 & 0.009 & $<0.005$ & $<0.005$ & $<0.005$ & na \\
\hline $\mathrm{Na}(\mathrm{mg} / \mathrm{L})$ & $<0.01$ & 0.01 & 0.01 & 0.01 & 0.04 & $<0.01$ & $<0.01$ & 0.02 & 0.02 \\
\hline $\mathrm{Ni}(\mu \mathrm{g} / \mathrm{L})$ & $<0.03$ & $<0.03$ & 0.06 & $<0.03$ & 0.04 & $<0.03$ & $<0.03$ & $<0.03$ & 0.03 \\
\hline $\mathrm{PO}_{4}$ as $\mathrm{P}(\mathrm{mg} / \mathrm{L})$ & $<0.002$ & $<0.002$ & 0.004 & 0.018 & $<0.002$ & $<0.002$ & $<0.002$ & 0.005 & na \\
\hline $\mathrm{Pb}(\mu \mathrm{g} / \mathrm{L})$ & $<0.009$ & $<0.009$ & $<0.009$ & $<0.009$ & $<0.009$ & $<0.009$ & $<0.009$ & $<0.009$ & $<0.009$ \\
\hline $\mathrm{SO}_{4}(\mathrm{mg} / \mathrm{L})$ & $<0.5$ & $<0.5$ & $<0.5$ & $<0.5$ & $<0.5$ & $<0.5$ & $<0.5$ & $<0.5$ & na \\
\hline $\mathrm{SiO}_{2}(\mathrm{mg} / \mathrm{L})$ & $<0.2$ & $<0.2$ & $<0.2$ & $<0.2$ & $<0.2$ & $<0.2$ & $<0.2$ & $<0.2$ & $<0.3$ \\
\hline $\operatorname{Sr}(\mu \mathrm{g} / \mathrm{L})$ & $<0.1$ & $<0.1$ & $<0.1$ & $<0.1$ & $<0.1$ & $<0.1$ & $<0.1$ & 1 & $<0.1$ \\
\hline $\mathrm{Tl}(\mu \mathrm{g} / \mathrm{L})$ & $<0.001$ & $<0.001$ & $<0.001$ & $<0.001$ & $<0.001$ & $<0.001$ & $<0.001$ & $<0.001$ & $<0.001$ \\
\hline $\mathrm{U}(\mu \mathrm{g} / \mathrm{L})$ & $<0.03$ & $<0.03$ & $<0.03$ & $<0.03$ & $<0.03$ & $<0.03$ & $<0.03$ & $<0.03$ & $<0.03$ \\
\hline$V(\mu g / L)$ & $<0.02$ & $<0.02$ & 0.02 & $<0.02$ & $<0.02$ & $<0.02$ & $<0.02$ & $<0.02$ & $<0.02$ \\
\hline $\mathrm{Zn}(\mu \mathrm{g} / \mathrm{L})$ & $<0.06$ & 0.16 & 0.20 & 0.30 & 0.10 & 0.11 & 0.15 & $<0.06$ & 0.25 \\
\hline
\end{tabular}

${ }^{1}$ Process blank is a blank that has been processed identically to field samples. 
Table 3.--Standard reference materials used in the determination of accurary during the May-June 1994 sampling

[All constituents reported in micrograms per liter, except $\mathrm{Ca}, \mathrm{Cl}, \mathrm{F}, \mathrm{Fe}, \mathrm{K}, \mathrm{Na}, \mathrm{SiO}_{2}$, and $\mathrm{SO}_{4}$, which are reported in milligrams per liter. Alkalinity reported in microequivalents per liter. Nitrite plus nitrate reported in milligrams per liter as nitrogen and orthophosphate reported in milligrams per liter as phosphorus; std. dev., standard deviation; na, not applicable; NBS, National Bureau of Standards; SLRS 2, St. Lawrence River System, reach 2; USGS, U.S. Geological Survey; SRWS, standard reference water sample]

NBS $1643 b$ 1/10 dilution ${ }^{1}$

\begin{tabular}{|c|c|c|c|c|}
\hline \multirow[b]{2}{*}{ Chemical constituent } & \multicolumn{2}{|c|}{ Measured value } & \multicolumn{2}{|c|}{ Certified value } \\
\hline & Mean & Std. dev. & Mean & Std. dev. \\
\hline Arsenic (As) & 5.05 & 0.18 & 4.9 & na \\
\hline Boron (B) & 10.6 & 1.6 & 9.4 & na \\
\hline Barium (Ba) & 4.45 & 0.11 & 4.4 & 0.2 \\
\hline Beryllium (Be) & 1.96 & 0.11 & 1.9 & 0.2 \\
\hline Cadmium (Cd) & 2.18 & 0.23 & 2.0 & 0.1 \\
\hline Cobalt (Co) & 2.86 & 0.05 & 2.6 & 0.1 \\
\hline Chromium (Cr) & 1.83 & 0.45 & 1.86 & 0.04 \\
\hline Copper $(\mathrm{Cu})$ & 2.05 & 0.06 & 2.19 & 0.04 \\
\hline Manganese (Mn) & 3.17 & 0.07 & 2.8 & 0.2 \\
\hline Molybdenum (Mo) & 9.8 & 0.2 & 8.5 & 0.3 \\
\hline Nickel (Ni) & 4.90 & 0.10 & 4.9 & 0.3 \\
\hline Lead $(\mathrm{Pb})$ & 2.28 & 0.06 & 2.37 & 0.07 \\
\hline Strontium (Sr) & 25.0 & 0.6 & 22.7 & 0.6 \\
\hline Thallium (Tl) & 0.75 & 0.02 & 0.80 & 0.02 \\
\hline Vanadium (V) & 5.16 & 0.47 & 4.52 & 0.04 \\
\hline Zinc (Zn) & 7.3 & 0.6 & 6.6 & 0.2 \\
\hline
\end{tabular}

National Research Council of Canada SLRS 2

\begin{tabular}{|c|c|c|c|c|}
\hline \multirow[b]{2}{*}{ Chemical constituent } & \multicolumn{2}{|c|}{ Measured value } & \multicolumn{2}{|c|}{ Certified value } \\
\hline & Mean & Std. dev. & Mean & Std. dev. \\
\hline Aluminum (Al) & 87.3 & 3.4 & 84.4 & 3.4 \\
\hline Arsenic (As) & 0.89 & 0.09 & 0.77 & 0.09 \\
\hline Barium (Ba) & 13.8 & 0.1 & 13.8 & 0.3 \\
\hline Cadmium (Cd) & 0.000 & 0.000 & 0.028 & 0.004 \\
\hline Cobalt (Co) & 0.051 & 0.014 & 0.063 & 0.012 \\
\hline Chromium (Cr) & 0.42 & 0.23 & 0.45 & 0.07 \\
\hline Copper $(\mathrm{Cu})$ & 2.94 & 0.11 & 2.76 & 0.17 \\
\hline Manganese (Mn) & 10.7 & 0.5 & 10.1 & 0.3 \\
\hline Molybdenum (Mo) & 0.15 & 0.02 & 0.16 & 0.02 \\
\hline Nickel (Ni) & 1.48 & 0.10 & 1.03 & 0.10 \\
\hline
\end{tabular}


Table 3.-Standard reference materials used in the determination of accuracy during the May-June 1994 sampling-Continued

\begin{tabular}{lccccc}
\hline & \multicolumn{2}{c}{ Measured value } & & \multicolumn{2}{c}{ Certified value } \\
\cline { 2 - 3 } Chemical constituent & Mean & Std. dev. & & Mean & Std. dev. \\
\hline Lead $(\mathrm{Pb})$ & 0.13 & 0.03 & & 0.129 & 0.011 \\
Strontium $(\mathrm{Sr})$ & 32.1 & 0.5 & & 27.3 & 0.4 \\
Uranium $(\mathrm{U})$ & 0.027 & 0.005 & & 0.049 & 0.002 \\
Vanadium $(\mathrm{V})$ & 0.45 & 0.56 & 0.25 & 0.06 \\
Zinc $(\mathrm{Zn})$ & 4.54 & 0.42 & 3.33 & 0.15
\end{tabular}

USGS SRWS T121

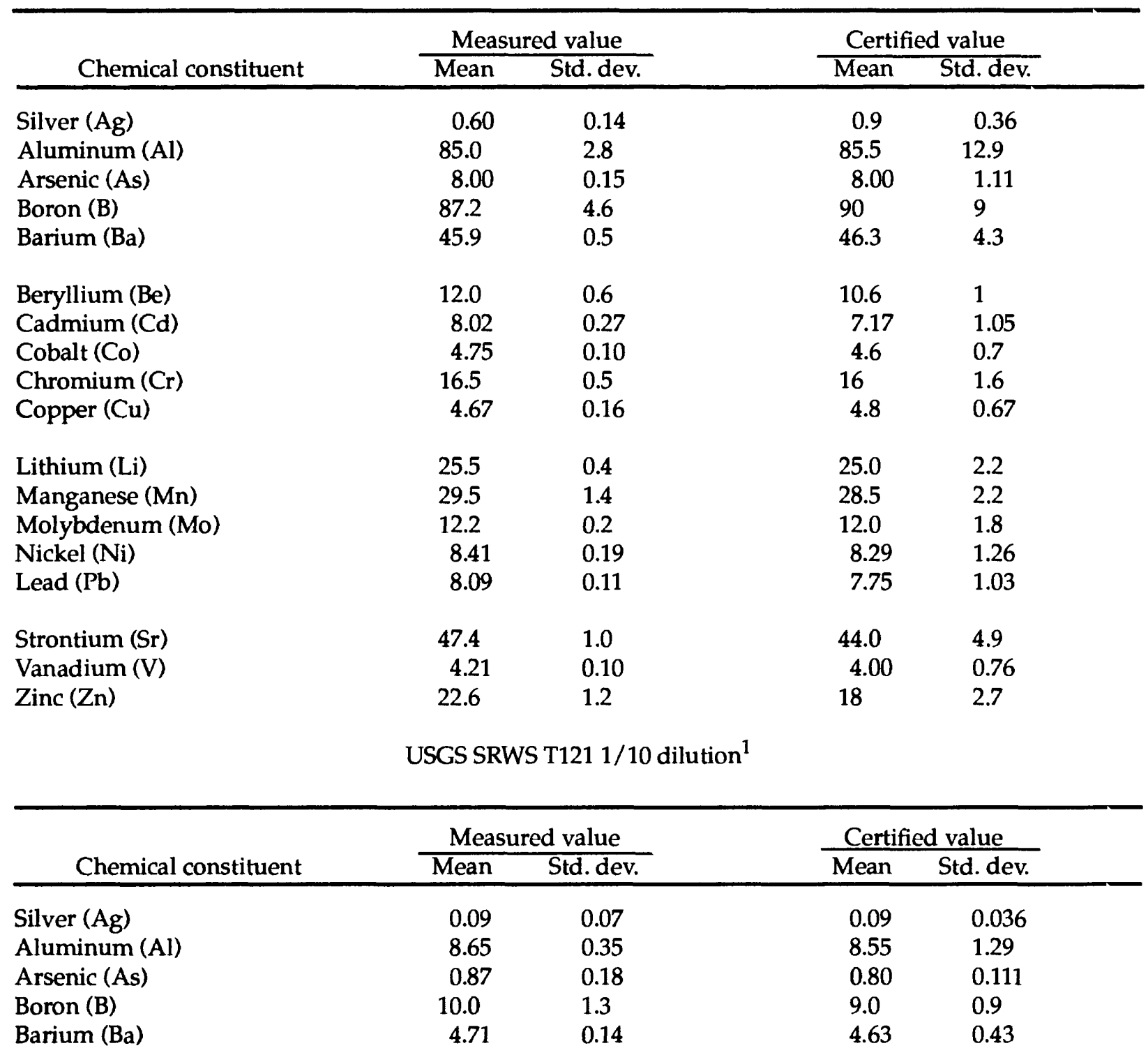


Table 3.--Standard reference materials used in the determination of accuracy during the May-June 1994 sampling--Continued

\begin{tabular}{|c|c|c|c|c|}
\hline \multirow[b]{2}{*}{ Chemical constituent } & \multicolumn{2}{|c|}{ Measured value } & \multicolumn{2}{|c|}{ Certified value } \\
\hline & Mean & Std. dev. & Mean & Std. dev. \\
\hline Beryllium (Be) & 1.11 & 0.05 & 1.06 & 0.1 \\
\hline Cadmium (Cd) & 0.74 & 0.08 & 0.717 & 0.105 \\
\hline Cobalt (Co) & 0.42 & 0.01 & 0.46 & 0.07 \\
\hline Chromium $(\mathrm{Cr})$ & 1.57 & 0.34 & 1.60 & 0.16 \\
\hline Copper $(\mathrm{Cu})$ & 0.48 & 0.03 & 0.48 & 0.067 \\
\hline Lithium (Li) & 2.27 & 0.09 & 2.50 & 0.22 \\
\hline Manganese (Mn) & 2.90 & 0.09 & 2.85 & 0.22 \\
\hline Molybdenum (Mo) & 1.31 & 0.06 & 1.20 & 0.18 \\
\hline Nickel (Ni) & 0.83 & 0.03 & 0.829 & 0.126 \\
\hline Lead $(\mathrm{Pb})$ & 0.85 & 0.06 & 0.775 & 0.103 \\
\hline Strontium (Sr) & 4.66 & 0.08 & 4.40 & 0.49 \\
\hline Vanadium (V) & 0.59 & 0.83 & 0.40 & 0.076 \\
\hline Zinc $(\mathrm{Zn})$ & 2.01 & 0.16 & 1.80 & 0.27 \\
\hline
\end{tabular}

USGS SRWS T125

\begin{tabular}{|c|c|c|c|c|}
\hline \multirow[b]{2}{*}{ Chemical constituent } & \multicolumn{2}{|c|}{ Measured value } & \multicolumn{2}{|c|}{ Certified value } \\
\hline & Mean & Std. dev. & Mean & Std. dev. \\
\hline Silver (Ag) & 3.93 & 0.08 & 3.83 & 0.604 \\
\hline Aluminum (Al) & 21.0 & 0.5 & 24.0 & 8.56 \\
\hline Arsenic (As) & 10.3 & 0.2 & 10.2 & 1.54 \\
\hline Boron (B) & 17.8 & 1.1 & 19.4 & 8.02 \\
\hline Barium (Ba) & 16.7 & 0.3 & 16.9 & 1.67 \\
\hline Beryllium (Be) & 17.1 & 0.9 & 15 & 1.19 \\
\hline Cadmium (Cd) & 7.94 & 0.30 & 7.2 & 0.749 \\
\hline Cobalt (Co) & 10.5 & 0.2 & 9.45 & 0.778 \\
\hline Chromium $(\mathrm{Cr})$ & 4.01 & 0.33 & 3.99 & 0.712 \\
\hline Copper $(\mathrm{Cu})$ & 17.4 & 0.7 & 17.4 & 2.08 \\
\hline Potassium (K) & 1.01 & 0.04 & 1.04 & 0.074 \\
\hline Lithium (Li) & 16.2 & 0.3 & 16.2 & 1.58 \\
\hline Manganese (Mn) & 18.4 & 0.8 & 18.0 & 1.22 \\
\hline Molybdenum (Mo) & 19.8 & 0.2 & 20.1 & 1.78 \\
\hline Nickel (Ni) & 11.8 & 0.2 & 11.2 & 1.04 \\
\hline Lead $(\mathrm{Pb})$ & 8.86 & 0.11 & 8.11 & 1.216 \\
\hline Strontium (Sr) & 50.5 & 0.9 & 46 & 2.29 \\
\hline Vanadium (V) & 8.02 & 0.84 & 6.56 & 0.89 \\
\hline Zinc $(\mathrm{Zn})$ & 5.10 & 0.40 & 5.95 & 4.007 \\
\hline
\end{tabular}


Table 3.--Standard reference materials used in the determination of accuracy during the May-June 1994 sampling--Continued

USGS SRWS T125 1/10 dilution ${ }^{1}$

\begin{tabular}{|c|c|c|c|c|}
\hline \multirow[b]{2}{*}{ Chemical constituent } & \multicolumn{2}{|c|}{ Measured value } & \multicolumn{2}{|c|}{ Certified value } \\
\hline & Mean & Std. dev. & Mean & Std. dev. \\
\hline Silver (Ag) & 0.40 & 0.03 & 0.38 & 0.06 \\
\hline Aluminum (Al) & 3.09 & 1.62 & 2.40 & 0.86 \\
\hline Arsenic (As) & 1.04 & 0.09 & 1.02 & 0.15 \\
\hline Boron (B) & 3.66 & 1.62 & 1.94 & 0.80 \\
\hline Barium (Ba) & 1.68 & 0.11 & 1.69 & 0.17 \\
\hline Beryllium (Be) & 1.60 & 0.08 & 1.50 & 0.12 \\
\hline Cadmium (Cd) & 0.61 & 0.05 & 0.72 & 0.07 \\
\hline Cobalt (Co) & 0.99 & 0.02 & 0.95 & 0.08 \\
\hline Chromium (Cr) & 0.34 & 0.33 & 0.40 & 0.07 \\
\hline Copper $(\mathrm{Cu})$ & 1.74 & 0.03 & 1.74 & 0.21 \\
\hline Lithium (Li) & 1.29 & 0.06 & 1.62 & 0.16 \\
\hline Manganese (Mn) & 1.79 & 0.06 & 1.80 & 0.12 \\
\hline Molybdenum (Mo) & 2.01 & 0.07 & 2.01 & 0.18 \\
\hline Nickel (Ni) & 1.17 & 0.04 & 1.12 & 0.10 \\
\hline Lead $(\mathrm{Pb})$ & 0.86 & 0.03 & 0.81 & 0.12 \\
\hline Strontium (Sr) & 4.93 & 0.08 & 4.60 & 0.23 \\
\hline Vanadium (V) & 0.88 & 0.50 & 0.66 & 0.09 \\
\hline Zinc $(\mathrm{Zn})$ & 0.45 & 0.06 & 0.60 & 0.40 \\
\hline \multicolumn{5}{|c|}{ USGS SRWS T103 } \\
\hline & \multicolumn{2}{|c|}{ Measured value } & \multicolumn{2}{|c|}{ Certified value } \\
\hline Chemical constituent & Mean & Std. dev. & Mean & Std. dev. \\
\hline Silver (Ag) & 3.93 & 0.08 & 3.83 & 0.604 \\
\hline Calcium (Ca) & 55.0 & 2.53 & 54.7 & 2.0 \\
\hline Iron $(\mathrm{Fe})$ & 0.042 & 0.004 & 0.041 & 0.0076 \\
\hline Magnesium (Mg) & 30.7 & 1.09 & 30.5 & 1.2 \\
\hline Sodium $(\mathrm{Na})$ & 96.1 & 9.61 & 107 & 5 \\
\hline Silica $\left(\mathrm{SiO}_{2}\right)$ & 6.97 & 0.44 & 7.5 & 0.2 \\
\hline
\end{tabular}


Table 3.--Standard reference materials used in the determination of accuracy during the May-June 1994 sampling--Continued

USGS SRWS T105

\begin{tabular}{|c|c|c|c|c|}
\hline \multirow[b]{2}{*}{ Chemical constituent } & \multicolumn{2}{|c|}{ Measured value } & \multicolumn{2}{|c|}{ Certified value } \\
\hline & Mean & Std. dev. & Mean & Std. dev. \\
\hline Calcium (Ca) & 73.1 & 2.4 & 73.0 & 4.2 \\
\hline Iron $(\mathrm{Fe})$ & 0.023 & 0.004 & 0.024 & 0.012 \\
\hline Magnesium (Mg) & 67.0 & 2.0 & 66.8 & 2.7 \\
\hline Sodium (Na) & 250 & 19 & 298 & 17 \\
\hline \multirow[t]{2}{*}{ Silica $\left(\mathrm{SiO}_{2}\right)$} & 24.5 & 1.4 & 25.4 & 1.5 \\
\hline & \multicolumn{2}{|c|}{ USGS SRWS T107 } & & \\
\hline
\end{tabular}

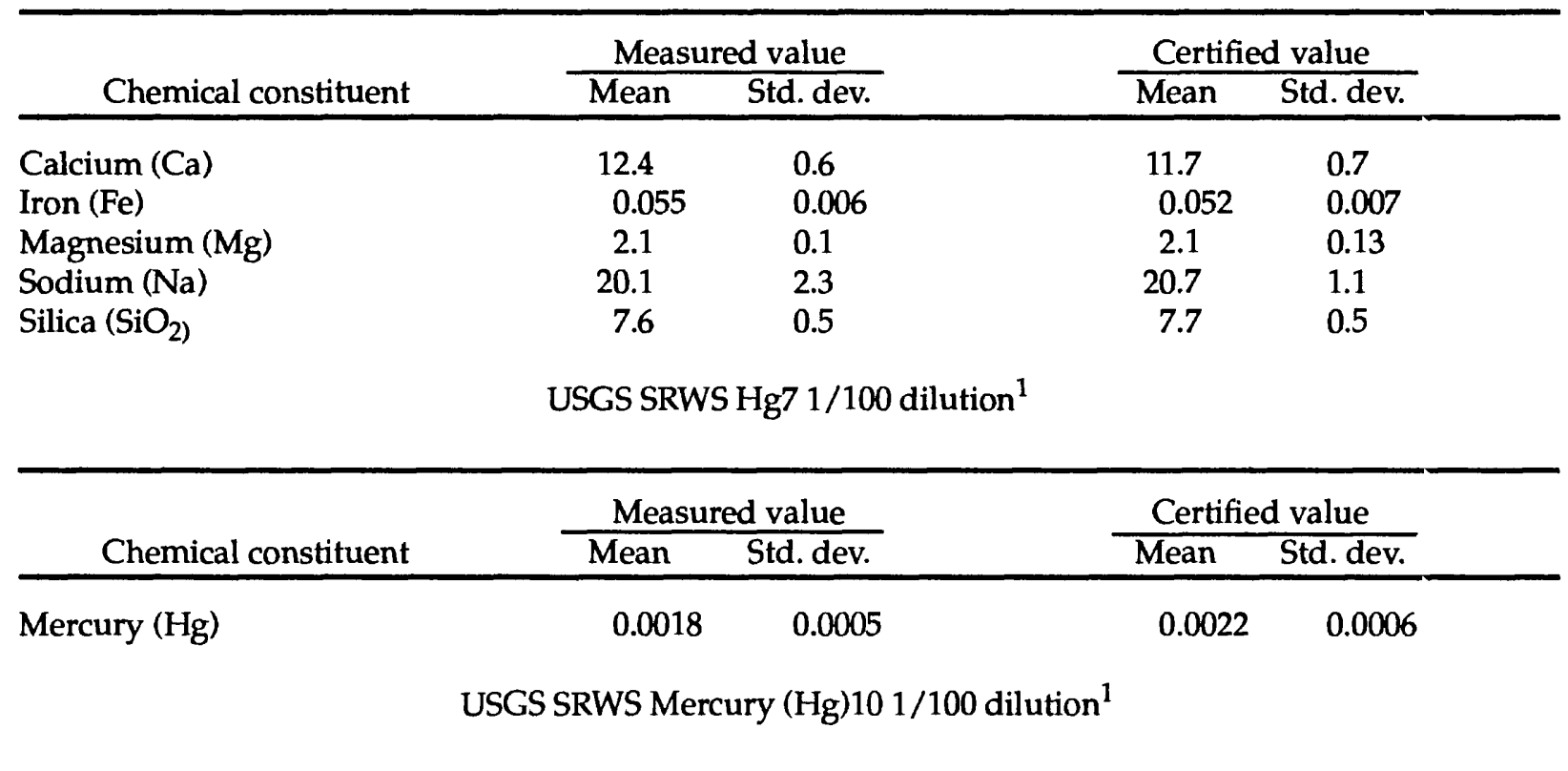

\begin{tabular}{|c|c|c|c|}
\hline \multirow[b]{2}{*}{ Chemical constituent } & Measured value & \multicolumn{2}{|c|}{ Certified value } \\
\hline & Mean $\quad$ Std. dev. & Mean & Std. dev. \\
\hline Mercury (Hg) & 0.0140 & 0.0140 & 0.0008 \\
\hline
\end{tabular}

USGS SRWS P15

\begin{tabular}{lcccccc}
\hline & \multicolumn{2}{c}{ Measured value } & & \multicolumn{2}{c}{ Certified value } \\
\cline { 2 - 5 } Chemical constituent & \multicolumn{2}{c}{ Mean } & Std. dev. & & Mean & Std. dev. \\
\hline Potassium $(\mathrm{K})$ & 0.14 & 0.01 & 0.19 & 0.02
\end{tabular}


Table 3.--Standard reference materials used in the determination of accuracy during the May-June 1994 sampling--Continued

USGS SRWS M112

\begin{tabular}{|c|c|c|c|}
\hline \multirow[b]{2}{*}{ Chemical constituent } & Measured value & \multicolumn{2}{|c|}{ Certified value } \\
\hline & Mean $\quad$ Std. dev. & Mean & Std. dev. \\
\hline Alkalinity & 567 & 759 & 10 \\
\hline
\end{tabular}

USGS SRWS M102

\begin{tabular}{llllll}
\hline \multirow{2}{*}{ Chemical constituent } & \multicolumn{2}{c}{ Measured value } & & \multicolumn{2}{c}{ Certified value } \\
\cline { 2 - 3 } Alkalinity & \multicolumn{2}{c}{ Mean } & Std. dev. & & \multicolumn{2}{c}{ Mean } & Std. dev. \\
\hline \multirow{2}{*}{3,529} & 18 & 3,517 & 20
\end{tabular}

USGS SRWS M94

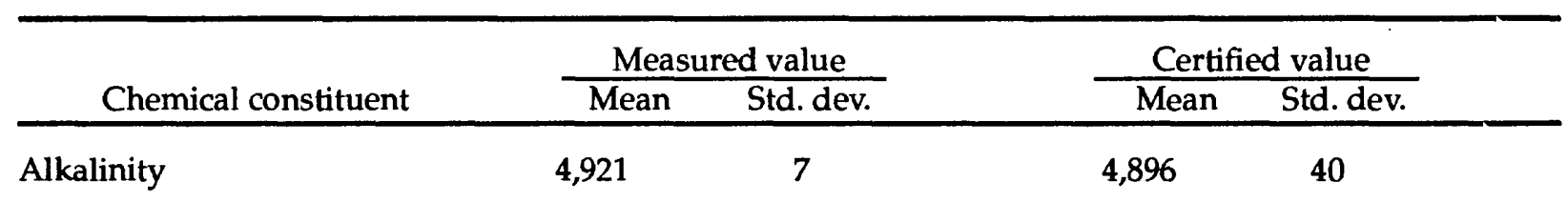

USGS SRWS N36

\begin{tabular}{lcccccc}
\hline & \multicolumn{2}{c}{ Measured value } & & \multicolumn{2}{c}{ Certified value } \\
\cline { 2 - 3 } \multicolumn{1}{c}{ Chemical constituent } & Mean & Std. dev. & & \multicolumn{2}{c}{ Mean } & Std. dev. \\
\hline Nitrogen $\left(\mathrm{NO}_{2}+\mathrm{NO}_{3}\right)$ & 0.184 & 0.011 & & 0.180 & 0.016 \\
Orthophosphate as $\mathrm{P}\left(\mathrm{PO}_{4}\right)$ & 0.196 & 0.006 & & 0.208 & 0.010
\end{tabular}

\section{USGS SRWS N38}

\begin{tabular}{|c|c|c|c|c|}
\hline \multirow[b]{2}{*}{ Chemical constituent } & \multicolumn{2}{|c|}{ Measured value } & \multicolumn{2}{|c|}{ Certified value } \\
\hline & Mean & Std. dev. & Mean & Std. dev. \\
\hline $\begin{array}{l}\text { Nitrogen }\left(\mathrm{NO}_{2}+\mathrm{NO}_{3}\right) \\
\text { Orthophosphate as } \mathrm{P}\left(\mathrm{PO}_{4}\right)\end{array}$ & $\begin{array}{l}0.220 \\
0.112\end{array}$ & $\begin{array}{l}0.002 \\
0.002\end{array}$ & $\begin{array}{l}0.210 \\
0.120\end{array}$ & $\begin{array}{l}0.018 \\
0.014\end{array}$ \\
\hline
\end{tabular}

USGS SRWS M6

\begin{tabular}{lcccccc}
\hline & \multicolumn{2}{c}{ Measured value } & & \multicolumn{2}{c}{ Certified value } \\
\cline { 2 - 3 } \cline { 5 - 6 } Chemical constituent & Mean & Std. dev. & & & Mean & Std. dev. \\
\hline Chloride $(\mathrm{Cl})$ & 12.7 & 0.1 & & 13.1 & 0.2 \\
Fluoride $(\mathrm{F})$ & 0.83 & 0.02 & & 0.85 & 0.02 \\
Sulfate $\left(\mathrm{SO}_{4}\right)$ & 74.8 & 1.0 & & 74.5 & 0.9
\end{tabular}


Table 3.--Standard reference materials used in the determination of accurary during the May-June 1994 sampling-Concluded

USGS SRWS M106

\begin{tabular}{lcccccc}
\hline & \multicolumn{2}{c}{ Measured value } & & \multicolumn{2}{c}{ Certified value } \\
\cline { 2 - 3 } \multicolumn{1}{c}{ Chemical constituent } & Mean & Std. dev. & & & Mean & Std. dev. \\
\hline Chloride $(\mathrm{Cl})$ & 13.1 & 0.0 & & 13 & \\
Fluoride $(\mathrm{F})$ & 0.30 & 0.01 & & 0.25 & 0.01 \\
Sulfate $\left(\mathrm{SO}_{4}\right)$ & 28.0 & 0.4 & & 27.6 & 0.4 \\
\hline
\end{tabular}

${ }^{1}$ These standard reference materials were diluted $1 / 10$ or $1 / 100$ to better cover the range of concentrations found in the samples. 
Table 4.--Standard reference materials used in the determination of accuracy during the October 1994 sampling

[All constituents reported in micrograms per liter, except $\mathrm{Ca}, \mathrm{Cl}, \mathrm{F}, \mathrm{Fe}, \mathrm{K}, \mathrm{Na}, \mathrm{SiO}_{2}$, and $\mathrm{SO}_{4}$, which are raported in milligrams per liter. Alkalinity reported in microequivalents per liter. Nitrite plus nitrate reported in milligrams per liter as nitrogen and orthophosphate reported in milligrams per liter as phosphorus; std. dev., standard deviation; na, not applicable; NBS, National Bureau of Standards; SLRS 2, St. Lawrence River System, reach 2; USGS, U.S. Geological Survey; SRWS, standard reference water sample]

NBS $1643 b$ 1/10 dilution ${ }^{1}$

\begin{tabular}{|c|c|c|c|c|}
\hline \multirow[b]{2}{*}{ Chemical constituent } & \multicolumn{2}{|c|}{ Measured value } & \multicolumn{2}{|c|}{ Certified value } \\
\hline & Mean & Std. dev. & Mean & Std. dev. \\
\hline Silver (Ag) & 1.21 & 0.03 & 0.98 & 0.08 \\
\hline Arsenic (As) & 5.50 & 0.32 & 4.9 & na \\
\hline Boron (B) & 10.0 & 1.8 & 9.4 & na \\
\hline Barium (Ba) & 4.57 & 0.13 & 4.4 & 0.2 \\
\hline Beryllium (Be) & 1.93 & 0.17 & 1.9 & 0.2 \\
\hline Cadmium (Cd) & 2.20 & 0.35 & 2.0 & 0.1 \\
\hline Cobalt (Co) & 2.88 & 0.14 & 2.6 & 0.1 \\
\hline Chromium (Cr) & 1.97 & 0.08 & 1.86 & 0.04 \\
\hline Copper $(\mathrm{Cu})$ & 2.10 & 0.09 & 2.19 & 0.04 \\
\hline Manganese (Mn) & 3.03 & 0.13 & 2.8 & 0.2 \\
\hline Molybdenum (Mo) & 9.46 & 0.29 & 8.5 & 0.3 \\
\hline Nickel (Ni) & 4.56 & 0.05 & 4.9 & 0.3 \\
\hline Lead $(\mathrm{Pb})$ & 2.63 & 0.37 & 2.37 & 0.07 \\
\hline Strontium (Sr) & 22.3 & 0.9 & 22.7 & 0.6 \\
\hline Thallium (Tl) & 0.79 & 0.03 & 0.80 & 0.02 \\
\hline Vanadium (V) & 4.46 & 0.13 & 4.52 & 0.04 \\
\hline Zinc $(\mathrm{Zn})$ & 8.47 & 0.25 & 6.6 & 0.2 \\
\hline
\end{tabular}

National Research Council of Canada SLRS 2

\begin{tabular}{lccccc}
\hline & \multicolumn{2}{c}{ Measured value } & & \multicolumn{2}{c}{ Certified value } \\
\cline { 2 - 3 } \cline { 5 - 6 } Chemical constituent & \multicolumn{2}{c}{ Mean } & Std. dev. & & \multicolumn{2}{c}{ Mean } & Std.dev. \\
\hline Aluminum (Al) & 89.2 & 5.8 & 84.4 & 3.4 \\
Arsenic (As) & 0.84 & 0.03 & 0.77 & 0.09 \\
Barium (Ba) & 14.8 & 1.3 & 13.8 & 0.3 \\
Cadmium (Cd) & 0.06 & 0.07 & 0.028 & 0.004 \\
Cobalt (Co) & 0.11 & 0.00 & 0.063 & 0.012 \\
& & & & \\
Chromium (Cr) & 0.60 & 0.12 & 0.45 & 0.07 \\
Copper (Cu) & 2.92 & 0.15 & & 2.76 & 0.17 \\
Manganese (Mn) & 10.4 & 0.5 & 10.1 & 0.3 \\
Molybdenum (Mo) & 0.17 & 0.02 & 0.16 & 0.02 \\
Nickel (Ni) & 1.48 & 0.08 & 1.03 & 0.1
\end{tabular}


Table 4.--Standard reference materials used in the determination of accuracy during the October 1994 sampling--Continued

\begin{tabular}{lccccc}
\hline & \multicolumn{2}{c}{ Measured value } & & \multicolumn{2}{c}{ Certified value } \\
\cline { 2 - 3 } \cline { 5 - 6 } Chemical constituent & Mean & Std. dev. & & Mean & Std. dev. \\
\hline Lead $(\mathrm{Pb})$ & 0.16 & 0.01 & & 0.129 & 0.011 \\
Strontium $(\mathrm{Sr})$ & 29.7 & 1.9 & & 27.3 & 0.4 \\
Uranium $(\mathrm{U})$ & 0.05 & 0.02 & 0.049 & 0.002 \\
Vanadium $(\mathrm{V})$ & 0.27 & 0.02 & 0.25 & 0.06 \\
Zinc $(\mathrm{Zn})$ & 4.98 & 0.41 & 3.33 & 0.15
\end{tabular}

USGS SRWS T121

\begin{tabular}{|c|c|c|c|c|}
\hline \multirow[b]{2}{*}{ Chemical constituent } & \multicolumn{2}{|c|}{ Measured value } & \multicolumn{2}{|c|}{ Certified value } \\
\hline & Mean & Std. dev. & Mean & Std. dev. \\
\hline Silver (Ag) & 0.34 & 0.15 & 0.90 & 0.36 \\
\hline Aluminum (Al) & 88.3 & 5.9 & 85.5 & 12.9 \\
\hline Arsenic (As) & 8.4 & 0.5 & 8.0 & 1.1 \\
\hline Boron (B) & 103 & 10 & 90 & 9 \\
\hline Barium (Ba) & 49.9 & 3.7 & 46.3 & 4.3 \\
\hline Beryllium (Be) & 11.6 & 0.9 & 10.6 & 1.0 \\
\hline Cadmium (Cd) & 6.7 & 0.4 & 7.2 & 1.1 \\
\hline Cobalt (Co) & 5.0 & 0.4 & 4.6 & 0.7 \\
\hline Chromium (Cr) & 18.3 & 1.3 & 16.0 & 1.6 \\
\hline Copper $(\mathrm{Cu})$ & 4.8 & 0.3 & 4.8 & 0.7 \\
\hline Lithium (Li) & 27.0 & 2.1 & 25.0 & 2.2 \\
\hline Manganese (Mn) & 29.1 & 1.4 & 28.5 & 2.2 \\
\hline Molybdenum (Mo) & 12.0 & 0.8 & 12.0 & 1.8 \\
\hline Nickel (Ni) & 8.4 & 0.4 & 8.3 & 1.3 \\
\hline Lead $(\mathrm{Pb})$ & 7.7 & 0.4 & 7.8 & 1.0 \\
\hline Strontium (Sr) & 44.5 & 2.6 & 44.0 & 4.9 \\
\hline Vanadium (V) & 3.9 & 0.2 & 4.0 & 0.8 \\
\hline \multirow[t]{2}{*}{ Zinc $(\mathrm{Zn})$} & 24.1 & 1.4 & 18.0 & 2.7 \\
\hline & \multicolumn{4}{|c|}{ USGS SRWS T121 1/10 dilution ${ }^{1}$} \\
\hline & \multicolumn{2}{|c|}{ Measured value } & \multicolumn{2}{|c|}{ Certified value } \\
\hline Chemical constituent & Mean & Std. dev. & Mean & Std. dev. \\
\hline Silver (Ag) & 0.05 & 0.09 & 0.09 & 0.04 \\
\hline Aluminum ( $\mathrm{Al})$ & 9.1 & 0.6 & 8.6 & 1.3 \\
\hline Arsenic (As) & 0.75 & 0.03 & 0.80 & 0.11 \\
\hline Boron (B) & 11.3 & 2.6 & 9.0 & 0.9 \\
\hline Barium (Ba) & 4.80 & 0.32 & 4.63 & 0.43 \\
\hline
\end{tabular}


Table 4.--Standard reference materials used in the determination of accuracy during the October 1994 sampling--Continued

\begin{tabular}{lccccc}
\hline & \multicolumn{2}{c}{ Measured value } & & \multicolumn{2}{c}{ Certified value } \\
\cline { 2 - 3 } \cline { 5 - 6 } Chemical constituent & Mean & Std. dev. & & Mean & Std. dev. \\
\hline Beryllium (Be) & 1.00 & 0.08 & & 1.06 & 0.10 \\
Cadmium (Cd) & 1.00 & 0.06 & & 0.72 & 0.11 \\
Cobalt (Co) & 0.49 & 0.02 & & 0.46 & 0.07 \\
Chromium (Cr) & 1.71 & 0.17 & 1.60 & 0.16 \\
Copper (Cu) & 0.49 & 0.04 & & 0.48 & 0.07 \\
& & & & \\
Lithium (Li) & 2.46 & 0.20 & & 2.50 & 0.22 \\
Manganese (Mn) & 2.80 & 0.10 & & 2.85 & 0.22 \\
Molybdenum (Mo) & 1.24 & 0.06 & & 1.20 & 0.18 \\
Nickel (Ni) & 0.82 & 0.04 & 0.83 & 0.13 \\
Lead (Pb) & 0.76 & 0.04 & & 0.78 & 0.10 \\
& & & & \\
Strontium (Sr) & 4.31 & 0.17 & & 4.40 & 0.49 \\
Vanadium (V) & 0.37 & 0.02 & 0.40 & 0.08 \\
Zinc (Zn) & 2.15 & 0.16 & 1.80 & 0.27
\end{tabular}

USGS SRWS T125

\begin{tabular}{lccccc}
\hline & \multicolumn{2}{c}{ Measured value } & \multicolumn{2}{c}{ Certified value } \\
\cline { 2 - 3 } \cline { 5 - 5 } Chemical constituent & Mean & Std. dev. & & Mean & Std. dev. \\
\hline Silver (Ag) & 4.34 & 0.26 & 3.83 & 0.60 \\
Aluminum (Al) & 21.4 & 1.4 & 24.0 & 8.6 \\
Arsenic (As) & 10.6 & 0.6 & 10.2 & 1.5 \\
Boron (B) & 20.1 & 2.6 & 19.4 & 8.0 \\
Barium (Ba) & 17.9 & 1.3 & 16.9 & 1.7 \\
& & & & \\
Beryllium (Be) & 16.0 & 1.3 & 15.0 & 1.2 \\
Calcium (Ca) & 9.4 & 0.2 & 9.3 & 0.5 \\
Cadmium (Cd) & 6.6 & 0.4 & 7.2 & 0.7 \\
Cobalt (Co) & 11.0 & 0.8 & 9.5 & 0.8 \\
Chromium (Cr) & 4.5 & 0.5 & 4.0 & 0.7 \\
& & & & \\
Copper (Cu) & 17.2 & 1.0 & 17.4 & 2.1 \\
Iron (Fe) & 0.091 & 0.002 & 0.098 & 0.007 \\
Lithium (Li) & 16.7 & 1.5 & 16.2 & 1.6 \\
Magnesium (Mg) & 2.00 & 0.01 & 2.00 & 0.11 \\
Manganese (Mn) & 18.0 & 1.0 & 18.0 & 1.2 \\
& & & & \\
Molybdenum (Mo) & 19.9 & 1.2 & 20.1 & 1.8 \\
Sodium (Na) & 23.0 & 3.0 & 22.3 & 1.2 \\
Nickel (Ni) & 11.6 & 0.6 & 11.2 & 1.0 \\
Lead (Pb) & 8.4 & 0.4 & 8.1 & 1.2 \\
Silica (SiO $)$ & 5.2 & 0.4 & 5.2 & 0.3 \\
& & & &
\end{tabular}


Table 4.--Standard reference materials used in the determination of accuracy during the October 1994 sampling--Continued

\begin{tabular}{lccccc}
\hline & \multicolumn{2}{c}{ Measured value } & & \multicolumn{2}{c}{ Certified value } \\
\cline { 2 - 3 } Chemical constituent & Mean & Std. dev. & & Mean & Std. dev. \\
\hline Strontium (Sr) & 46.4 & 2.7 & & 46.0 & 2.3 \\
Vanadium (V) & 7.0 & 0.4 & 6.6 & 0.9 \\
Zinc (Zn) & 5.4 & 0.4 & 6.0 & 4.0
\end{tabular}

USGS SRWS T125 1/10 dilution ${ }^{1}$

\begin{tabular}{lccccc}
\hline & \multicolumn{2}{c}{ Measured value } & & \multicolumn{2}{c}{ Certified value } \\
\cline { 2 - 3 } \cline { 5 - 6 } Chemical constituent & Mean & Std. dev. & & Mean & Std. dev. \\
\hline Silver (Ag) & 0.45 & 0.04 & 0.38 & 0.06 \\
Aluminum (Al) & 1.81 & 0.52 & 2.40 & 0.86 \\
Arsenic (As) & 0.98 & 0.08 & 1.02 & 0.15 \\
Boron (B) & 2.11 & 2.04 & 1.94 & 0.80 \\
Barium (Ba) & 1.69 & 0.34 & 1.69 & 0.17 \\
Beryllium (Be) & & & & \\
Cadmium (Cd) & 1.49 & 0.13 & 1.50 & 0.12 \\
Cobalt (Co) & 0.76 & 0.04 & 0.72 & 0.07 \\
Chromium (Cr) & 1.10 & 0.09 & 0.95 & 0.08 \\
Copper (Cu) & 0.58 & 0.34 & 0.40 & 0.07 \\
& 1.76 & 0.12 & 1.74 & 0.21 \\
Lithium (Li) & & & & \\
Manganese (Mn) & 1.58 & 0.18 & 1.62 & 0.16 \\
Molybdenum (Mo) & 1.81 & 0.13 & 1.80 & 0.12 \\
Nickel (Ni) & 2.04 & 0.14 & 2.01 & 0.18 \\
Lead (Pb) & 1.17 & 0.06 & 1.12 & 0.10 \\
& 0.83 & 0.06 & 0.81 & 0.12 \\
Strontium (Sr) & & & & \\
Vanadium (V) & 4.68 & 0.27 & 4.60 & 0.23 \\
Zinc (Zn) & 0.72 & 0.06 & 0.66 & 0.09 \\
& 0.58 & 0.11 & 0.60 & 0.40
\end{tabular}

High Purity Standards Certified Water Sample

\begin{tabular}{lccccc}
\hline & \multicolumn{2}{c}{ Measured value } & & \multicolumn{2}{c}{ Certified value } \\
\cline { 2 - 3 } \multicolumn{1}{c}{ Chemical constituent } & Mean & Std. dev. & & Mean & Std. dev. \\
\hline Silver (Ag) & 2.48 & 0.01 & 2.50 & 0.13 \\
Aluminum (Al) & 112.8 & 4.1 & & 115.0 & 5.8 \\
Arsenic (As) & 62.3 & 6.0 & 80.0 & 4.0 \\
Barium (Ba) & 54.8 & 1.5 & 50.0 & 2.5 \\
Beryllium (Be) & 14.5 & 0.2 & 20.0 & 1.0
\end{tabular}


Table 4.--Standard reference materials used in the determination of accuracy during the October 1994 sampling--Continued

\begin{tabular}{|c|c|c|c|c|}
\hline \multirow[b]{2}{*}{ Chemical constituent } & \multicolumn{2}{|c|}{ Measured value } & \multicolumn{2}{|c|}{ Certified value } \\
\hline & Mean & Std. dev. & Mean & Std. dev. \\
\hline Cadmium (Cd) & 8.8 & 0.4 & 12.0 & 0.6 \\
\hline Cobalt (Co) & 26.7 & 0.2 & 25.0 & 1.3 \\
\hline Chromium (Cr) & 22.0 & 1.1 & 20.0 & 1.0 \\
\hline Copper $(\mathrm{Cu})$ & 17.0 & 0.6 & 20.0 & 1.0 \\
\hline Lithium (Li) & 15.5 & 0.6 & 15.0 & 0.8 \\
\hline Manganese (Mn) & 32.6 & 0.2 & 35.0 & 1.8 \\
\hline Molybdenum (Mo) & 94.0 & 3.7 & 100.0 & 5.0 \\
\hline Nickel (Ni) & 55.7 & 1.2 & 60.0 & 3.0 \\
\hline Lead $(\mathrm{Pb})$ & 30.7 & 1.6 & 35.0 & 1.8 \\
\hline Strontium (Sr) & 228 & 11 & 250 & 13 \\
\hline Thallium (Tl) & 8.4 & 0.3 & 10.0 & 0.5 \\
\hline Vanadium (V) & 28.4 & 1.3 & 30.0 & 1.5 \\
\hline Zinc $(\mathrm{Zn})$ & 49.6 & 2.7 & 70.0 & 3.5 \\
\hline
\end{tabular}

USGS SRWS T103

\begin{tabular}{|c|c|c|c|c|}
\hline \multirow[b]{2}{*}{ Chemical constituent } & \multicolumn{2}{|c|}{ Measured value } & \multicolumn{2}{|c|}{ Certified value } \\
\hline & Mean & Std. dev. & Mean & Std. dev. \\
\hline Calcium (Ca) & 55.2 & 2.7 & 54.7 & 2 \\
\hline Iron $(\mathrm{Fe})$ & 0.042 & 0.005 & 0.041 & 0.008 \\
\hline Magnesium (Mg) & 31.2 & 0.8 & 30.5 & 1.2 \\
\hline Sodium $(\mathrm{Na})$ & 101.5 & 7.0 & 107 & 5 \\
\hline Silica $\left(\mathrm{SiO}_{2}\right)$ & 7.4 & 0.3 & 7.5 & 0.2 \\
\hline
\end{tabular}

USGS SRWS T105

\begin{tabular}{lcccccc}
\hline & \multicolumn{2}{c}{ Measured value } & & \multicolumn{2}{c}{ Certified value } \\
\cline { 2 - 3 } \multicolumn{1}{c}{ Chemical constituent } & Mean & Std. dev. & & & Mean & Std. dev. \\
\hline Calcium $(\mathrm{Ca})$ & 71.9 & 2.5 & & 73 & 4.2 \\
Iron $(\mathrm{Fe})$ & 0.019 & 0.005 & & 0.024 & 0.012 \\
Magnesium $(\mathrm{Mg})$ & 67.7 & 1.3 & & 66.8 & 2.7 \\
Sodium $(\mathrm{Na})$ & 242 & 12 & & 298 & 17 \\
Silica $\left(\mathrm{SiO}_{2}\right)$ & 25.0 & 0.9 & & 25.4 & 1.5
\end{tabular}


Table 4.--Standard reference materials used in the determination of accuracy during the October 1994 sampling--Continued

\section{USGS SRWS T107}

\begin{tabular}{|c|c|c|c|c|}
\hline \multirow[b]{2}{*}{ Chemical constituent } & \multicolumn{2}{|c|}{ Measured value } & \multicolumn{2}{|c|}{ Certified value } \\
\hline & Mean & Std. dev. & Mean & Std. dev. \\
\hline Calcium (Ca) & 12.2 & 0.4 & 11.7 & 0.7 \\
\hline Iron $(\mathrm{Fe})$ & 0.052 & 0.005 & 0.052 & 0.007 \\
\hline Magnesium (Mg) & 2.2 & 0.0 & 2.1 & 0.13 \\
\hline Sodium $(\mathrm{Na})$ & 20.9 & 1.4 & 20.7 & 1.1 \\
\hline Silica $\left(\mathrm{SiO}_{2}\right)$ & 8.1 & 0.4 & 7.7 & 0.5 \\
\hline
\end{tabular}

USGS SRWS Hg7 1/100 dilution ${ }^{1}$

\begin{tabular}{|c|c|c|c|c|}
\hline \multirow[b]{2}{*}{ Chemical constituent } & \multicolumn{2}{|c|}{ Measured value } & \multicolumn{2}{|c|}{ Certified value } \\
\hline & Mean & Std. dev. & Mean & Std. dev. \\
\hline Mercury $(\mathrm{Hg})$ & 0.002 & 0.0005 & 0.0022 & 0.0006 \\
\hline
\end{tabular}

\begin{tabular}{lcccccc}
\hline & \multicolumn{2}{c}{ Measured value } & & \multicolumn{2}{c}{ Certified value } \\
\cline { 2 - 3 } \cline { 5 - 6 } Chemical constituent & Mean & Std. dev. & & Mean & Std. dev. \\
\hline Mercury (Hg) & 0.0153 & 0.0007 & & 0.014 & 0.0008
\end{tabular}

USGS SRWS P14

\begin{tabular}{lcccccc}
\hline & \multicolumn{2}{c}{ Measured value } & & \multicolumn{2}{c}{ Certified value } \\
\cline { 2 - 3 } Chemical constituent & Mean & Std. dev. & & & Mean & Std. dev. \\
\hline Potassium $(\mathrm{K})$ & 0.65 & 0.05 & & 0.65 & 0.08
\end{tabular}

USGS SRWS M102

\begin{tabular}{|c|c|c|c|c|}
\hline \multirow[b]{2}{*}{ Chemical constituent } & \multicolumn{2}{|c|}{ Measured value } & \multicolumn{2}{|c|}{ Certified value } \\
\hline & Mean & Std. dev. & Mean & Std. dev. \\
\hline Alkalinity & 3,501 & 6 & 3,517 & 20 \\
\hline
\end{tabular}

USGS SRWS M122

\begin{tabular}{|c|c|c|c|c|}
\hline \multirow[b]{2}{*}{ Chemical constituent } & \multicolumn{2}{|c|}{ Measured value } & \multicolumn{2}{|c|}{ Certified value } \\
\hline & Mean & Std. dev. & Mean & Std. dev. \\
\hline Alkalinity & 728 & 6 & 759 & 28 \\
\hline
\end{tabular}


Table 4.--Standard reference materials used in the determination of accuracy during the October 1994 sampling--Continued

USGS SRWS M130

\begin{tabular}{llllll}
\hline \multirow{2}{*}{ Chemical constituent } & \multicolumn{2}{c}{ Measured value } & & \multicolumn{2}{c}{ Certified value } \\
\cline { 2 - 3 } Alkalinity & \multicolumn{2}{c}{ Mean } & Std. dev. & & \multicolumn{2}{c}{ Mean } & Std. dev. \\
\hline 1,099 & 11 & 1,199 & 38
\end{tabular}

USGS SRWS N32

\begin{tabular}{|c|c|c|c|c|}
\hline \multirow[b]{2}{*}{ Chemical constituent } & \multicolumn{2}{|c|}{ Measured value } & \multicolumn{2}{|c|}{ Certified value } \\
\hline & Mean & Std. dev. & Mean & Std. dev. \\
\hline Ammonium ion as nitrogen $\left(\mathrm{NH}_{4}\right)$ & 0.036 & 0.002 & 0.040 & 0.021 \\
\hline Nitrogen $\left(\mathrm{NO}_{2}+\mathrm{NO}_{3}\right)$ & 0.135 & 0.004 & 0.148 & 0.024 \\
\hline Orthophosphate as $\mathrm{P}\left(\mathrm{PO}_{4}\right)$ & 0.086 & 0.014 & 0.091 & 0.01 \\
\hline
\end{tabular}

USGS SRWS N36

\begin{tabular}{|c|c|c|}
\hline & Measured value & Certified value \\
\hline Chemical constituent & Mean Std. dev. & Mean Std. dev. \\
\hline
\end{tabular}

$\begin{array}{lllll}\text { Ammonium ion as nitrogen }\left(\mathrm{NH}_{4}\right) & 0.124 & 0.001 & 0.110 & 0.015 \\ \text { Nitrogen }\left(\mathrm{NO}_{2}+\mathrm{NO}_{3}\right) & 0.172 & 0.015 & 0.180 & 0.016 \\ \text { Orthophosphate as } \mathrm{P}\left(\mathrm{PO}_{4}\right) & 0.217 & 0.009 & 0.208 & 0.01\end{array}$

USGS SRWS N38

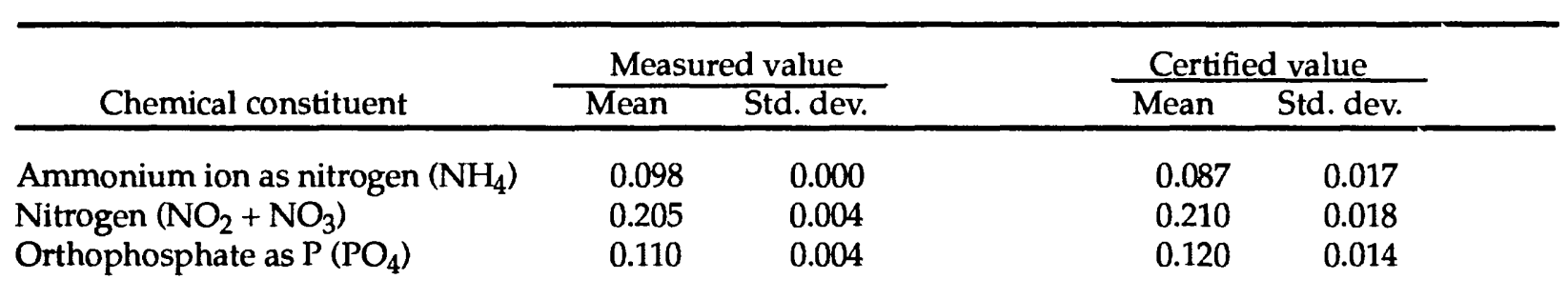

USGS SRWS M6

\begin{tabular}{lcccccc}
\hline & \multicolumn{2}{c}{ Measured value } & & \multicolumn{2}{c}{ Certified value } \\
\cline { 2 - 3 } \multicolumn{1}{c}{ Chemical constituent } & Mean & Std. dev. & & & Mean & Std. dev. \\
\hline Chloride $(\mathrm{Cl})$ & 13.5 & 0.5 & & 13 & $\left({ }^{2}\right)$ \\
Fluoride $(\mathrm{F})$ & 0.84 & 0.01 & & 0.85 & 0.02 \\
Sulfate $\left(\mathrm{SO}_{4}\right)$ & 69.9 & 0.3 & & 74.5 & 0.9
\end{tabular}


Table 4.--Standard reference materials used in the determination of accuracy during the October 1994 sampling--Concluded

USGS SRWS M106

\begin{tabular}{lccccc}
\hline & \multicolumn{2}{c}{ Measured value } & & \multicolumn{2}{c}{ Certified value } \\
\cline { 2 - 3 } \cline { 5 - 6 } \multicolumn{1}{c}{ Chemical constituent } & \multicolumn{2}{c}{ Mean } & Std. dev. & & \multicolumn{2}{c}{ Mean } & Std. dev. \\
\hline Chloride $(\mathrm{Cl})$ & 14.2 & 0.5 & & 13.1 & 0.2 \\
Fluoride $(\mathrm{F})$ & 0.26 & 0.00 & & 0.25 & 0.01 \\
Potassium $(\mathrm{K})$ & 0.61 & 0.05 & & 0.7 & $\left(^{2}\right)$ \\
Sulfate $\left(\mathrm{SO}_{4}\right)$ & 28.6 & 0.1 & & 27.6 & 0.4 \\
\hline
\end{tabular}

${ }^{1}$ These standard reference materials were diluted $1 / 10$ or $1 / 100$ to better cover the range of concentrations found in the samples.

${ }^{2}$ No certified standard deviation available. 
Table 5.-Standard reference material NIST ${ }^{1}$ Buffalo River sediment used in the determination of accuracy for suspended sediments for the May-June and October 1994 samplings

[All constituents reported in micrograms per gram. Std. dev., standard deviation]

\begin{tabular}{|c|c|c|c|c|}
\hline \multirow[b]{2}{*}{ Chemical constituent } & \multicolumn{2}{|c|}{ Measured value } & \multicolumn{2}{|c|}{ Certified value } \\
\hline & Mean & Std. dev. & Mean & Std. dev. \\
\hline Aluminum (Al) & 48,900 & 6,600 & 61,100 & 1,600 \\
\hline Arsenic (As) & 23.7 & 2.5 & 23.4 & 0.8 \\
\hline Barium (Ba) & 279 & 24 & 414 & 12 \\
\hline Calcium (Ca) & 24,200 & 400 & 26,000 & 300 \\
\hline Cadmium (Cd) & 3.56 & 0.40 & 3.45 & 0.22 \\
\hline Cobalt (Co) & 16.3 & 0.3 & 14.0 & 0.6 \\
\hline Chromium (Cr) & 154 & 3 & 135 & 5 \\
\hline Copper $(\mathrm{Cu})$ & 97.3 & 5.4 & 98.6 & 5 \\
\hline Iron $(\mathrm{Fe})$ & 39,500 & 400 & 41,100 & 1,000 \\
\hline Mercury $(\mathrm{Hg})$ & 1.36 & 0.03 & 1.47 & 0.07 \\
\hline Lithium (Li) & 36.3 & 1.6 & 47.5 & 4.1 \\
\hline Magnesium (Mg) & 7,100 & 2,300 & 12,000 & 200 \\
\hline Manganese (Mn) & 544 & 9 & 555 & 19 \\
\hline Sodium (Na) & 5,590 & 30 & 5,470 & 140 \\
\hline Nickel (Ni) & 41.4 & 2.1 & 44.1 & 3 \\
\hline Lead $(\mathrm{Pb})$ & 145 & 2 & 161 & 17 \\
\hline Silica $\left(\mathrm{SiO}_{2}\right)$ & 664,000 & 3,000 & 622,000 & 2,800 \\
\hline Strontium (Sr) & 131 & 7 & 130 & \\
\hline Titanium (Ti) & 4,830 & 70 & 4,570 & 180 \\
\hline Thallium (Tl) & 0.98 & 0.01 & 1.06 & 0.07 \\
\hline Uranium (U) & 2.77 & 0.03 & 3.13 & 0.13 \\
\hline Vanadium (V) & 86 & 6 & 95 & 4 \\
\hline Zinc $(\mathrm{Zn})$ & 451 & 6 & 438 & 12 \\
\hline
\end{tabular}

${ }^{1}$ National Institute of Standards and Technology. 
Table 6.--Spiked recovery data for samples collected during the May-June 1994 sampling

[All constituents reported in micrograms per liter. WWTP, wastewater treatment plant; na, not applicable]

\begin{tabular}{|c|c|c|c|c|c|c|c|}
\hline $\begin{array}{c}\text { Trace } \\
\text { element }\end{array}$ & Site & $\begin{array}{c}\text { Site } \\
\text { number } \\
\text { (fig. 1) }\end{array}$ & $\begin{array}{c}\text { Indigenous } \\
\text { concen- } \\
\text { tration }\end{array}$ & $\begin{array}{l}\text { Spiked } \\
\text { concen- } \\
\text { tration }\end{array}$ & $\begin{array}{c}\text { Difference in } \\
\text { concen- } \\
\text { trations }\end{array}$ & $\begin{array}{c}\text { Theoretical } \\
\text { concen- } \\
\text { tration }\end{array}$ & $\begin{array}{l}\text { Per'ent } \\
\text { recovery }\end{array}$ \\
\hline \multirow[t]{8}{*}{ Silver (Ag) } & Bernalillo & S1 & 0.00 & 9.55 & 9.55 & 13.20 & 72.4 \\
\hline & Paseo & S2 & 0.00 & 11.30 & 11.30 & 13.20 & $\varepsilon 5.6$ \\
\hline & Central & S3 & 0.00 & 11.14 & 11.14 & 13.20 & $\varepsilon 4.4$ \\
\hline & Rio Bravo & S4 & 0.00 & 12.87 & 12.87 & 13.20 & S7.5 \\
\hline & WWTP & S5 & 0.21 & 10.82 & 10.61 & 13.20 & $\varepsilon 0.4$ \\
\hline & I-25 Bridge & S6 & 0.00 & 11.87 & 11.87 & 13.20 & $\varepsilon 9.9$ \\
\hline & Isleta & S7 & 0.01 & 15.18 & 15.16 & 13.20 & 114.9 \\
\hline & Blank & na & 0.08 & 14.01 & 13.93 & 13.20 & $1 C 5.5$ \\
\hline \multirow[t]{8}{*}{ Arsenic (As) } & Bernalillo & S1 & 1.24 & 59.87 & 58.63 & 66.01 & 88.8 \\
\hline & Paseo & S2 & 1.41 & 60.82 & 59.40 & 66.01 & 90.0 \\
\hline & Central & S3 & 1.43 & 61.62 & 60.20 & 66.01 & 91.2 \\
\hline & Rio Bravo & S4 & 1.39 & 60.41 & 59.03 & 66.01 & 89.4 \\
\hline & WWTP & S5 & 8.14 & 68.61 & 60.47 & 66.01 & 91.6 \\
\hline & I-25 Bridge & S6 & 1.61 & 61.14 & 59.53 & 66.01 & 97.2 \\
\hline & Isleta & S7 & 1.77 & 61.31 & 59.54 & 66.01 & 97.2 \\
\hline & Blank & na & 0.07 & 56.65 & 56.58 & 66.01 & 85.7 \\
\hline \multirow{8}{*}{ Beryllium (Be) } & Bernalillo & S1 & 0.01 & 1.40 & 1.39 & 1.32 & 105.2 \\
\hline & Paseo & S2 & 0.00 & 1.33 & 1.32 & 1.32 & 107.2 \\
\hline & Central & S3 & 0.01 & 1.37 & 1.36 & 1.32 & 103.1 \\
\hline & Rio Bravo & S4 & 0.00 & 1.36 & 1.36 & 1.32 & 103.0 \\
\hline & WWTP & S5 & 0.00 & 1.30 & 1.30 & 1.32 & $9^{\circ} 6$ \\
\hline & I-25 Bridge & S6 & 0.00 & 1.36 & 1.35 & 1.32 & 102.6 \\
\hline & Isleta & S7 & 0.01 & 1.34 & 1.34 & 1.32 & 101.2 \\
\hline & Blank & na & 0.00 & 1.32 & 1.32 & 1.32 & 107.2 \\
\hline \multirow{8}{*}{ Cadmium (Cd) } & Bernalillo & S1 & 0.00 & 1.12 & 1.12 & 1.32 & $8^{-} .0$ \\
\hline & Paseo & S2 & 0.00 & 1.14 & 1.14 & 1.32 & 85.0 \\
\hline & Central & S3 & 0.00 & 1.14 & 1.14 & 1.32 & 85.2 \\
\hline & Rio Bravo & S4 & 0.00 & 1.15 & 1.15 & 1.32 & 85.8 \\
\hline & WWTP & S5 & 0.01 & 1.23 & 1.23 & 1.32 & 93.0 \\
\hline & I-25 Bridge & S6 & 0.00 & 1.15 & 1.15 & 1.32 & 85.8 \\
\hline & Isleta & S7 & 0.00 & 1.11 & 1.11 & 1.32 & 81.4 \\
\hline & Blank & na & 0.00 & 1.04 & 1.04 & 1.32 & $7^{\wedge 9}$ \\
\hline \multirow[t]{8}{*}{ Cobalt (Co) } & Bernalillo & S1 & 0.12 & 6.97 & 6.85 & 6.60 & 103.8 \\
\hline & Paseo & S2 & 0.09 & 6.84 & 6.75 & 6.60 & 102.3 \\
\hline & Central & S3 & 0.13 & 7.08 & 6.94 & 6.60 & $10^{-} .2$ \\
\hline & Rio Bravo & S4 & 0.11 & 6.91 & 6.80 & 6.60 & 103.0 \\
\hline & WWTP & S5 & 0.24 & 7.13 & 6.89 & 6.60 & $10^{4} \cdot 4$ \\
\hline & I-25 Bridge & S6 & 0.10 & 6.90 & 6.80 & 6.60 & 103.1 \\
\hline & Isleta & S7 & 0.13 & 7.00 & 6.87 & 6.60 & $10^{x} .1$ \\
\hline & Blank & na & 0.00 & 6.48 & 6.48 & 6.60 & $9^{\circ} 2$ \\
\hline
\end{tabular}


Table 6.--Spiked recovery data for samples collected during the May-June 1994 sampling--Continued

\begin{tabular}{|c|c|c|c|c|c|c|c|}
\hline $\begin{array}{c}\text { Trace } \\
\text { element }\end{array}$ & Site & $\begin{array}{c}\text { Site } \\
\text { number } \\
\text { (fig. 1) }\end{array}$ & $\begin{array}{c}\text { Indigenous } \\
\text { concen- } \\
\text { tration }\end{array}$ & $\begin{array}{l}\text { Spiked } \\
\text { concen- } \\
\text { tration }\end{array}$ & $\begin{array}{c}\text { Difference in } \\
\text { concen- } \\
\text { trations }\end{array}$ & $\begin{array}{c}\text { Theoretical } \\
\text { concen- } \\
\text { tration }\end{array}$ & $\begin{array}{l}\text { Percent } \\
\text { recovery }\end{array}$ \\
\hline \multirow{8}{*}{$\begin{array}{l}\text { Chromium } \\
\text { (Cr) }\end{array}$} & Bernalillo & $\mathrm{S} 1$ & 0.08 & 13.12 & 13.04 & 13.20 & $9^{\circ} 8$ \\
\hline & Paseo & $\mathrm{S} 2$ & 0.02 & 13.24 & 13.22 & 13.20 & 107.1 \\
\hline & Central & S3 & 0.11 & 13.70 & 13.59 & 13.20 & 102.9 \\
\hline & Rio Bravo & $\mathrm{S} 4$ & 0.00 & 13.30 & 13.30 & 13.20 & 101.7 \\
\hline & WWTP & S5 & 0.67 & 14.35 & 13.68 & 13.20 & 103.7 \\
\hline & I-25 Bridge & S6 & 0.03 & 13.45 & 13.41 & 13.20 & 101.6 \\
\hline & Isleta & S7 & 0.12 & 13.40 & 13.28 & 13.20 & 107.6 \\
\hline & Blank & na & 0.40 & 13.03 & 12.64 & 13.20 & $9 \div .7$ \\
\hline \multirow{8}{*}{ Copper $(\mathrm{Cu})$} & Bernalillo & S1 & 1.50 & 57.95 & 56.45 & 66.01 & $8 \div .5$ \\
\hline & Paseo & S2 & 1.58 & 59.34 & 57.77 & 66.01 & 87.5 \\
\hline & Central & S3 & 1.52 & 62.03 & 60.50 & 66.01 & 91.7 \\
\hline & Rio Bravo & S4 & 1.45 & 60.26 & 58.80 & 66.01 & $8 ? .1$ \\
\hline & WWTP & S5 & 4.80 & 61.43 & 56.64 & 66.01 & $8 \div 8$ \\
\hline & I-25 Bridge & S6 & 1.46 & 60.72 & 59.26 & 66.01 & $8 ? .8$ \\
\hline & Isleta & S7 & 1.39 & 58.46 & 57.07 & 66.01 & 85.4 \\
\hline & Blank & na & 0.01 & 59.84 & 59.84 & 66.01 & 90.6 \\
\hline \multirow[t]{8}{*}{ Mercury $(\mathrm{Hg})$} & Bernalillo & S1 & 0.0015 & 0.0061 & 0.0046 & 0.0052 & $8 ? .0$ \\
\hline & Paseo & S2 & 0.0012 & na & na & na & na \\
\hline & Central & S3 & 0.0014 & 0.0067 & 0.0053 & 0.0052 & 102.6 \\
\hline & Rio Bravo & S4 & 0.0016 & 0.0076 & 0.0060 & 0.0054 & 111.1 \\
\hline & WWTP & S5 & 0.0048 & 0.0096 & 0.0048 & 0.0052 & 92.6 \\
\hline & I-25 Bridge & S6 & 0.0007 & 0.0068 & 0.0061 & 0.0052 & 116.8 \\
\hline & Isleta & S7 & 0.0022 & 0.0074 & 0.0052 & 0.0050 & 10.4 .4 \\
\hline & Blank & na & 0 & 0.0060 & 0.0060 & 0.0052 & 115.4 \\
\hline \multirow[t]{8}{*}{ Nickel (Ni) } & Bernalillo & $\mathrm{S} 1$ & 4.18 & 62.26 & 58.08 & 66.01 & 88.0 \\
\hline & Paseo & $\mathrm{S} 2$ & 3.15 & 62.03 & 58.88 & 66.01 & 87.2 \\
\hline & Central & S3 & 2.98 & 64.41 & 61.42 & 66.01 & 93.1 \\
\hline & Rio Bravo & S4 & 2.99 & 61.86 & 58.87 & 66.01 & 89.2 \\
\hline & WWTP & S5 & 5.37 & 64.88 & 59.51 & 66.01 & 90.1 \\
\hline & I-25 Bridge & S6 & 3.03 & 62.30 & 59.27 & 66.01 & 89.8 \\
\hline & Isleta & S7 & 3.59 & 61.94 & 58.35 & 66.01 & 88.4 \\
\hline & Blank & na & 0.04 & 57.78 & 57.74 & 66.01 & 87.5 \\
\hline \multirow[t]{8}{*}{ Lead $(\mathrm{Pb})$} & Bernalillo & $\mathrm{S} 1$ & 0.09 & 15.14 & 15.05 & 13.20 & 114.0 \\
\hline & Paseo & S2 & 0.03 & 14.84 & 14.81 & 13.20 & 112.2 \\
\hline & Central & S3 & 0.15 & 14.97 & 14.83 & 13.20 & 112.3 \\
\hline & Rio Bravo & $\mathrm{S} 4$ & 0.08 & 15.01 & 14.92 & 13.20 & 113.0 \\
\hline & WWTP & S5 & 0.47 & 15.68 & 15.20 & 13.20 & 115.2 \\
\hline & I-25 Bridge & S6 & 0.04 & 15.05 & 15.01 & 13.20 & 113.7 \\
\hline & Isleta & S7 & 0.05 & 14.96 & 14.92 & 13.20 & 113.0 \\
\hline & Blank & na & 0.00 & 13.88 & 13.88 & 13.20 & 105.2 \\
\hline
\end{tabular}


Table 6.-Spiked recovery data for samples collected during the May-June 1994 sampling--Concluded

\begin{tabular}{|c|c|c|c|c|c|c|c|}
\hline $\begin{array}{c}\text { Trace } \\
\text { element }\end{array}$ & Site & $\begin{array}{c}\text { Site } \\
\text { number } \\
\text { (fig. 1) }\end{array}$ & $\begin{array}{l}\text { Indigenous } \\
\text { concen- } \\
\text { tration }\end{array}$ & $\begin{array}{l}\text { Spiked } \\
\text { concen- } \\
\text { tration }\end{array}$ & $\begin{array}{c}\text { Difference in } \\
\text { concen- } \\
\text { trations }\end{array}$ & $\begin{array}{l}\text { Theoretical } \\
\text { concen- } \\
\text { tration }\end{array}$ & $\begin{array}{l}\text { Per-ent } \\
\text { recovery }\end{array}$ \\
\hline \multirow[t]{8}{*}{ Uranium (U) } & Bernalillo & S1 & 1.43 & 73.02 & 71.59 & 66.01 & $1 C^{\circ .5}$ \\
\hline & Paseo & S2 & 1.50 & 71.29 & 69.79 & 66.01 & $1 C \uparrow .7$ \\
\hline & Central & S3 & 1.50 & 72.16 & 70.66 & 66.01 & 107.0 \\
\hline & Rio Bravo & S4 & 1.48 & 72.54 & 71.06 & 66.01 & $1 C 7.6$ \\
\hline & WWTP & S5 & 1.37 & 76.37 & 75.00 & 66.01 & 113.6 \\
\hline & I-25 Bridge & S6 & 1.48 & 72.16 & 70.69 & 66.01 & 107.1 \\
\hline & Isleta & S7 & 1.56 & 73.07 & 71.51 & 66.01 & 108.3 \\
\hline & Blank & na & 0.00 & 63.24 & 63.24 & 66.01 & 95.8 \\
\hline \multirow[t]{8}{*}{ Zinc $(\mathrm{Zn})$} & Bernalillo & S1 & 0.65 & 69.81 & 69.16 & 66.01 & 104.8 \\
\hline & Paseo & S2 & 0.83 & 71.86 & 71.03 & 66.01 & 107.6 \\
\hline & Central & S3 & 0.89 & 71.82 & 70.93 & 66.01 & 107.5 \\
\hline & Rio Bravo & S4 & 1.05 & 70.93 & 69.88 & 66.01 & 105.9 \\
\hline & WWTP & S5 & 19.65 & 88.06 & 68.42 & 66.01 & 103.6 \\
\hline & I-25 Bridge & S6 & 1.03 & 70.71 & 69.68 & 66.01 & 105.6 \\
\hline & Isleta & S7 & 0.87 & 70.77 & 69.90 & 66.01 & 105.9 \\
\hline & Blank & na & 0.13 & 68.59 & 68.46 & 66.01 & 103.7 \\
\hline
\end{tabular}


Table 7.--Spiked recovery data for samples collected during the October 1994 sampling

[All constituents reported in micrograms per liter. WWTP, wastewater treatment plant; na, not applicable]

\begin{tabular}{|c|c|c|c|c|c|c|c|}
\hline Element & Site & $\begin{array}{c}\text { Site } \\
\text { number } \\
\text { (fig. 1) }\end{array}$ & $\begin{array}{l}\text { Indigenous } \\
\text { concen- } \\
\text { tration }\end{array}$ & $\begin{array}{l}\text { Spiked } \\
\text { concen- } \\
\text { tration }\end{array}$ & $\begin{array}{l}\text { Difference in } \\
\text { concen- } \\
\text { trations }\end{array}$ & $\begin{array}{l}\text { Theoretical } \\
\text { concen- } \\
\text { tration }\end{array}$ & $\begin{array}{l}\text { Percent } \\
\text { recovery }\end{array}$ \\
\hline Silver (Ag) & $\begin{array}{l}\text { Bernalillo } \\
\text { Paseo } \\
\text { Central } \\
\text { Rio Bravo } \\
\text { WWTP } \\
\text { I-25 Bridge } \\
\text { Isleta } \\
\text { Blank }\end{array}$ & $\begin{array}{l}\text { S1 } \\
\text { S2 } \\
\text { S3 } \\
\text { S4 } \\
\text { S5 } \\
\text { S6 } \\
\text { S7 } \\
\text { na }\end{array}$ & $\begin{array}{l}0.00 \\
0.00 \\
0.00 \\
0.00 \\
0.06 \\
0.00 \\
0.00 \\
0.00\end{array}$ & $\begin{array}{r}13.22 \\
10.26 \\
13.99 \\
15.25 \\
6.99 \\
8.15 \\
14.12 \\
14.92\end{array}$ & $\begin{array}{r}13.22 \\
10.26 \\
13.99 \\
15.25 \\
6.93 \\
8.15 \\
14.12 \\
14.92\end{array}$ & $\begin{array}{l}13.20 \\
13.20 \\
13.20 \\
13.20 \\
13.20 \\
13.20 \\
13.20 \\
13.20\end{array}$ & $\begin{array}{r}100.2 \\
77.7 \\
106.0 \\
115.5 \\
52.5 \\
61.7 \\
106.9 \\
113.0\end{array}$ \\
\hline Arsenic (As) & $\begin{array}{l}\text { Bernalillo } \\
\text { Paseo } \\
\text { Central } \\
\text { Rio Bravo } \\
\text { WWTP } \\
\text { I-25 Bridge } \\
\text { Isleta } \\
\text { Blank }\end{array}$ & $\begin{array}{l}\text { S1 } \\
\text { S2 } \\
\text { S3 } \\
\text { S4 } \\
\text { S5 } \\
\text { S6 } \\
\text { S7 } \\
\text { na }\end{array}$ & $\begin{array}{l}1.85 \\
2.54 \\
2.32 \\
2.42 \\
8.57 \\
3.37 \\
3.51 \\
0.00\end{array}$ & $\begin{array}{l}70.93 \\
71.78 \\
66.19 \\
73.21 \\
76.80 \\
70.93 \\
70.89 \\
57.60\end{array}$ & $\begin{array}{l}69.08 \\
69.24 \\
63.87 \\
70.79 \\
68.22 \\
67.57 \\
67.38 \\
57.60\end{array}$ & $\begin{array}{l}66.01 \\
66.01 \\
66.01 \\
66.01 \\
66.01 \\
66.01 \\
66.01 \\
66.01\end{array}$ & $\begin{array}{r}104.6 \\
104.9 \\
96.8 \\
107.2 \\
103.4 \\
102.4 \\
102.1 \\
87.3\end{array}$ \\
\hline $\begin{array}{l}\text { Beryllium } \\
\text { (Be) }\end{array}$ & $\begin{array}{l}\text { Bernalillo } \\
\text { Paseo } \\
\text { Central } \\
\text { Rio Bravo } \\
\text { WWTP } \\
\text { I-25 Bridge } \\
\text { Isleta } \\
\text { Blank }\end{array}$ & $\begin{array}{l}\text { S1 } \\
\text { S2 } \\
\text { S3 } \\
\text { S4 } \\
\text { S5 } \\
\text { S6 } \\
\text { S7 } \\
\text { na }\end{array}$ & $\begin{array}{l}0.00 \\
0.00 \\
0.00 \\
0.00 \\
0.00 \\
0.00 \\
0.00 \\
0.00\end{array}$ & $\begin{array}{l}1.386 \\
1.438 \\
1.320 \\
1.382 \\
1.378 \\
1.376 \\
1.356 \\
1.207\end{array}$ & $\begin{array}{l}1.38 \\
1.44 \\
1.32 \\
1.38 \\
1.38 \\
1.37 \\
1.35 \\
1.21\end{array}$ & $\begin{array}{l}1.32 \\
1.32 \\
1.32 \\
1.32 \\
1.32 \\
1.32 \\
1.32 \\
1.32\end{array}$ & $\begin{array}{r}104.9 \\
108.7 \\
100.0 \\
104.5 \\
104.4 \\
103.9 \\
102.5 \\
91.4\end{array}$ \\
\hline $\begin{array}{l}\text { Cadmium } \\
\text { (Cd) }\end{array}$ & $\begin{array}{l}\text { Bernalillo } \\
\text { Paseo } \\
\text { Central } \\
\text { Rio Bravo } \\
\text { WWTP } \\
\text { I-25 Bridge } \\
\text { Isleta } \\
\text { Blank }\end{array}$ & $\begin{array}{l}\text { S1 } \\
\text { S2 } \\
\text { S3 } \\
\text { S4 } \\
\text { S5 } \\
\text { S6 } \\
\text { S7 } \\
\text { na }\end{array}$ & $\begin{array}{l}0.00 \\
0.00 \\
0.00 \\
0.00 \\
0.00 \\
0.00 \\
0.00 \\
0.00\end{array}$ & $\begin{array}{l}1.24 \\
1.2 \\
1.2 \\
1.2 \\
1.3 \\
1.2 \\
1.2 \\
1.0\end{array}$ & $\begin{array}{l}1.24 \\
1.21 \\
1.17 \\
1.21 \\
1.28 \\
1.21 \\
1.23 \\
1.03\end{array}$ & $\begin{array}{l}1.32 \\
1.32 \\
1.32 \\
1.32 \\
1.32 \\
1.32 \\
1.32 \\
1.32\end{array}$ & $\begin{array}{l}94.0 \\
91.7 \\
88.8 \\
91.8 \\
96.6 \\
91.3 \\
93.2 \\
78.3\end{array}$ \\
\hline Cobalt (Co) & $\begin{array}{l}\text { Bernalillo } \\
\text { Paseo } \\
\text { Central } \\
\text { Rio Bravo } \\
\text { WWTP } \\
\text { I-25 Bridge } \\
\text { Isleta } \\
\text { Blank }\end{array}$ & $\begin{array}{l}\text { S1 } \\
\text { S2 } \\
\text { S3 } \\
\text { S4 } \\
\text { S5 } \\
\text { S6 } \\
\text { S7 } \\
\text { na }\end{array}$ & $\begin{array}{l}0.03 \\
0.02 \\
0.01 \\
0.00 \\
0.22 \\
0.09 \\
0.07 \\
0.00\end{array}$ & $\begin{array}{l}8.03 \\
8.20 \\
7.68 \\
8.23 \\
8.28 \\
8.07 \\
8.02 \\
7.27\end{array}$ & $\begin{array}{l}8.01 \\
8.18 \\
7.67 \\
8.23 \\
8.07 \\
7.99 \\
7.95 \\
7.27\end{array}$ & $\begin{array}{l}6.60 \\
6.60 \\
6.60 \\
6.60 \\
6.60 \\
6.60 \\
6.60 \\
6.60\end{array}$ & $\begin{array}{l}121.3 \\
123.9 \\
116.2 \\
124.6 \\
122.2 \\
121.0 \\
120.4 \\
110.2\end{array}$ \\
\hline
\end{tabular}


Table 7.--Spiked recovery data for samples collected during the October 1994 sampling--Continued

\begin{tabular}{|c|c|c|c|c|c|c|c|}
\hline Element & Site & $\begin{array}{c}\text { Site } \\
\text { number } \\
\text { (fig. 1) }\end{array}$ & $\begin{array}{c}\text { Indigenous } \\
\text { concen- } \\
\text { tration }\end{array}$ & $\begin{array}{l}\text { Spiked } \\
\text { concen- } \\
\text { tration }\end{array}$ & $\begin{array}{l}\text { Difference in } \\
\text { concen- } \\
\text { trations }\end{array}$ & $\begin{array}{c}\text { Theoretical } \\
\text { concen- } \\
\text { tration }\end{array}$ & $\begin{array}{l}\text { Percent } \\
\text { reccuery }\end{array}$ \\
\hline \multirow{8}{*}{$\begin{array}{l}\text { Chromium } \\
\text { (Cr) }\end{array}$} & Bernalillo & $\mathrm{S1}$ & 0.43 & 17.12 & 16.69 & 13.20 & 126.4 \\
\hline & Paseo & $\mathrm{S} 2$ & 0.49 & 17.26 & 16.77 & 13.20 & 127.0 \\
\hline & Central & S3 & 0.49 & 15.94 & 15.45 & 13.20 & 117.0 \\
\hline & Rio Bravo & S4 & 0.43 & 17.23 & 16.80 & 13.20 & 127.3 \\
\hline & WWTP & S5 & 4.69 & 20.93 & 16.23 & 13.20 & 123.0 \\
\hline & I-25 Bridge & S6 & 0.93 & 17.22 & 16.29 & 13.20 & 123.4 \\
\hline & Isleta & S7 & 0.85 & 17.20 & 16.35 & 13.20 & 123.9 \\
\hline & Blank & na & 0.06 & 14.22 & 14.17 & 13.20 & 107.3 \\
\hline \multirow[t]{8}{*}{ Copper $(\mathrm{Cu})$} & Bernalillo & S1 & 0.93 & 67.78 & 66.84 & 66.01 & 101.3 \\
\hline & Paseo & S2 & 1.01 & 67.58 & 66.56 & 66.01 & 100.8 \\
\hline & Central & S3 & 0.96 & 62.77 & 61.81 & 66.01 & 93.6 \\
\hline & Rio Bravo & S4 & 1.01 & 68.74 & 67.74 & 66.01 & 102.6 \\
\hline & WWTP & S5 & 8.83 & 75.40 & 66.57 & 66.01 & 100.8 \\
\hline & I-25 Bridge & S6 & 1.61 & 66.56 & 64.96 & 66.01 & 99.4 \\
\hline & Isleta & S7 & 1.29 & 67.61 & 66.32 & 66.01 & 100.5 \\
\hline & Blank & na & 0.00 & 60.61 & 60.61 & 66.01 & 91.8 \\
\hline \multirow[t]{8}{*}{ Mercury $(\mathrm{Hg})$} & Bernalillo & S1 & 0.0009 & 0.0064 & 0.0055 & 0.0052 & 105.8 \\
\hline & Paseo & S2 & 0.0008 & 0.0071 & 0.0063 & 0.0052 & 121.9 \\
\hline & Central & S3 & 0.0007 & 0.0075 & 0.0068 & 0.0050 & $1: 5.1$ \\
\hline & Rio Bravo & S4 & 0.0009 & 0.0075 & 0.0066 & 0.0050 & $1: 2.0$ \\
\hline & WWTP & S5 & 0.0026 & 0.0080 & 0.0054 & 0.0050 & 108.6 \\
\hline & I-25 Bridge & S6 & 0.0013 & 0.0068 & 0.0055 & 0.0052 & 106.4 \\
\hline & Isleta & S7 & 0.0012 & 0.0075 & 0.0063 & 0.0050 & $1 \% .5$ \\
\hline & Blank & na & 0.0010 & 0.0070 & 0.0060 & 0.0050 & 127.0 \\
\hline \multirow[t]{8}{*}{ Nickel (Ni) } & Bernalillo & $\mathrm{S} 1$ & 0.77 & 63.61 & 62.85 & 66.01 & 05.2 \\
\hline & Paseo & $\mathrm{S} 2$ & 0.82 & 64.63 & 63.81 & 66.01 & 95.7 \\
\hline & Central & S3 & 0.96 & 61.75 & 60.79 & 66.01 & 92.1 \\
\hline & Rio Bravo & $\mathrm{S4}$ & 0.75 & 65.67 & 64.92 & 66.01 & 09.4 \\
\hline & WWTP & S5 & 3.70 & 66.30 & 62.60 & 66.01 & 94.8 \\
\hline & I-25 Bridge & S6 & 1.14 & 63.88 & 62.74 & 66.01 & 95.0 \\
\hline & Isleta & S7 & 1.16 & 65.50 & 64.35 & 66.01 & 97.5 \\
\hline & Blank & na & 0.00 & 58.62 & 58.62 & 66.01 & $\varepsilon 9.8$ \\
\hline \multirow[t]{8}{*}{ Lead $(\mathrm{Pb})$} & Bernalillo & $\mathrm{S} 1$ & 0.01 & 15.597 & 15.58 & 13.20 & $1 丁 8.1$ \\
\hline & Paseo & $\mathrm{S} 2$ & 0.01 & 15.670 & 15.66 & 13.20 & 118.6 \\
\hline & Central & S3 & 0.02 & 15.364 & 15.34 & 13.20 & 116.2 \\
\hline & Rio Bravo & $\mathrm{S} 4$ & 0.01 & 15.597 & 15.59 & 13.20 & 118.1 \\
\hline & WWTP & S5 & 0.27 & 16.092 & 15.83 & 13.20 & $1 \top 9.9$ \\
\hline & I-25 Bridge & S6 & 0.03 & 16.040 & 16.01 & 13.20 & 121.3 \\
\hline & Isleta & S7 & 0.03 & 15.950 & 15.92 & 13.20 & 127.6 \\
\hline & Blank & na & 0.00 & 12.935 & 12.94 & 13.20 & @9.0 \\
\hline
\end{tabular}


Table 7.--Spiked recovery data for samples collected during the October 1994 sampling--Concluded

\begin{tabular}{llcccccc}
\hline Element & Site & $\begin{array}{c}\text { Site } \\
\text { number } \\
\text { (fig. 1) }\end{array}$ & $\begin{array}{c}\text { Indigenous } \\
\text { concen- } \\
\text { tration }\end{array}$ & $\begin{array}{c}\text { Spiked } \\
\text { concen- } \\
\text { tration }\end{array}$ & $\begin{array}{c}\text { Difference in } \\
\text { concen- } \\
\text { trations }\end{array}$ & $\begin{array}{c}\text { Theoretical } \\
\text { concen- } \\
\text { tration }\end{array}$ & $\begin{array}{c}\text { Percent } \\
\text { recovery }\end{array}$ \\
\hline Uranium (U) & Bernalillo & S1 & 2.76 & 90.03 & 87.27 & 66.01 & 132.2 \\
& Paseo & S2 & 3.01 & 91.60 & 88.60 & 66.01 & 134.2 \\
& Central & S3 & 2.90 & 90.65 & 87.75 & 66.01 & 132.9 \\
& Rio Bravo & S4 & 2.90 & 90.77 & 87.87 & 66.01 & 133.1 \\
& WWTP & S5 & 1.29 & 92.21 & 90.92 & 66.01 & 137.7 \\
& I-25 Bridge & S6 & 2.83 & 93.48 & 90.65 & 66.01 & 137.3 \\
& Isleta & S7 & 2.94 & 93.22 & 90.28 & 66.01 & 136.8 \\
& Blank & na & 0.00 & 68.66 & 68.66 & 66.01 & 104.0 \\
& & & & & & & \\
Zinc (Zn) & Bernalillo & S1 & 0.38 & 85.31 & 84.93 & 66.01 & 128.7 \\
& Paseo & S2 & 0.48 & 84.62 & 84.14 & 66.01 & 127.5 \\
& Central & S3 & 0.79 & 76.97 & 76.18 & 66.01 & 115.4 \\
& Rio Bravo & S4 & 0.36 & 86.29 & 85.93 & 66.01 & 130.2 \\
& WWTP & S5 & 17.37 & 99.44 & 82.07 & 66.01 & 124.3 \\
& I-25 Bridge & S6 & 1.84 & 82.50 & 80.67 & 66.01 & 122.2 \\
& Isleta & S7 & 1.49 & 80.25 & 78.75 & 66.01 & 119.3 \\
& Blank & na & 0.15 & 76.84 & 76.68 & 66.01 & 116.2 \\
\hline
\end{tabular}




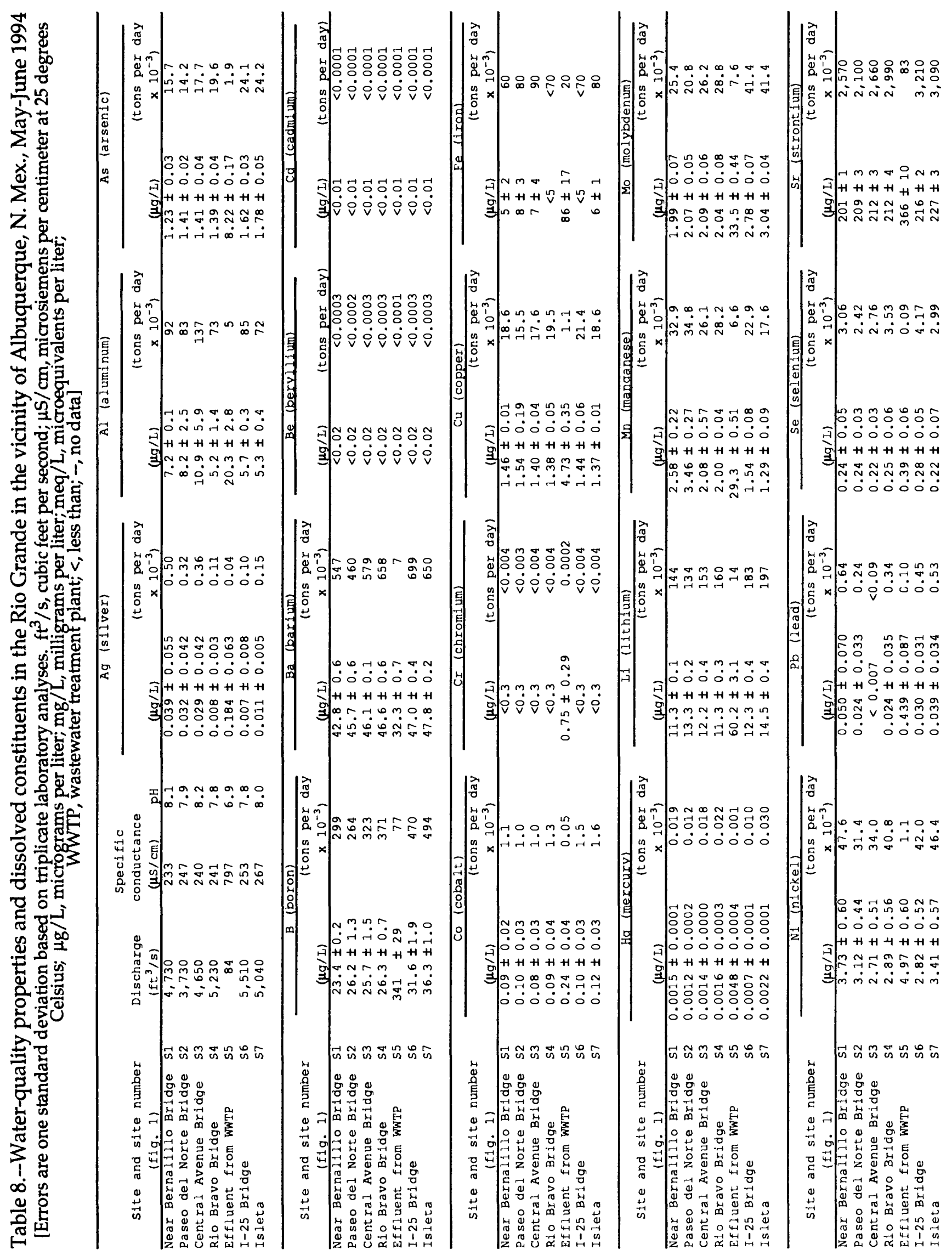




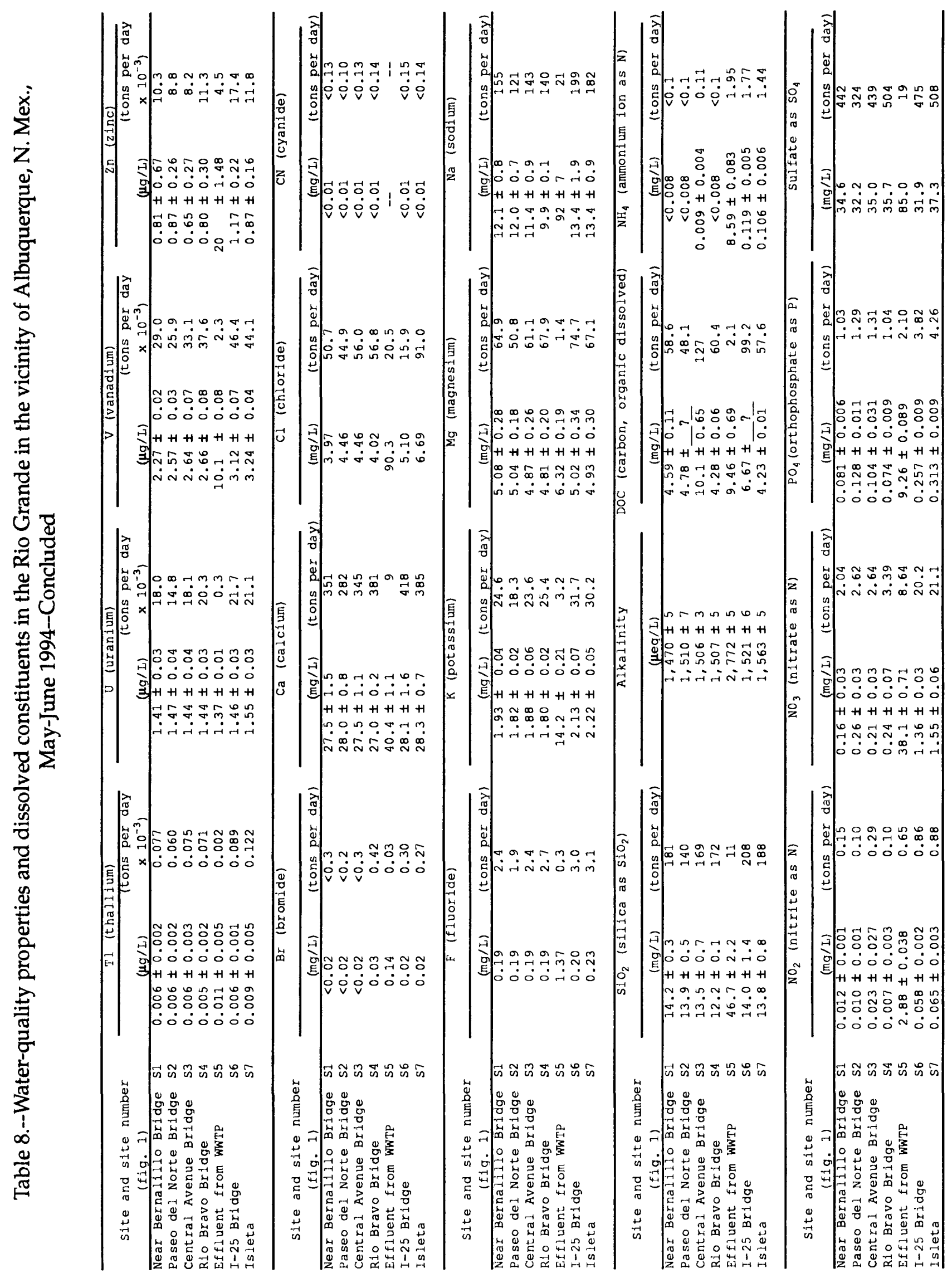




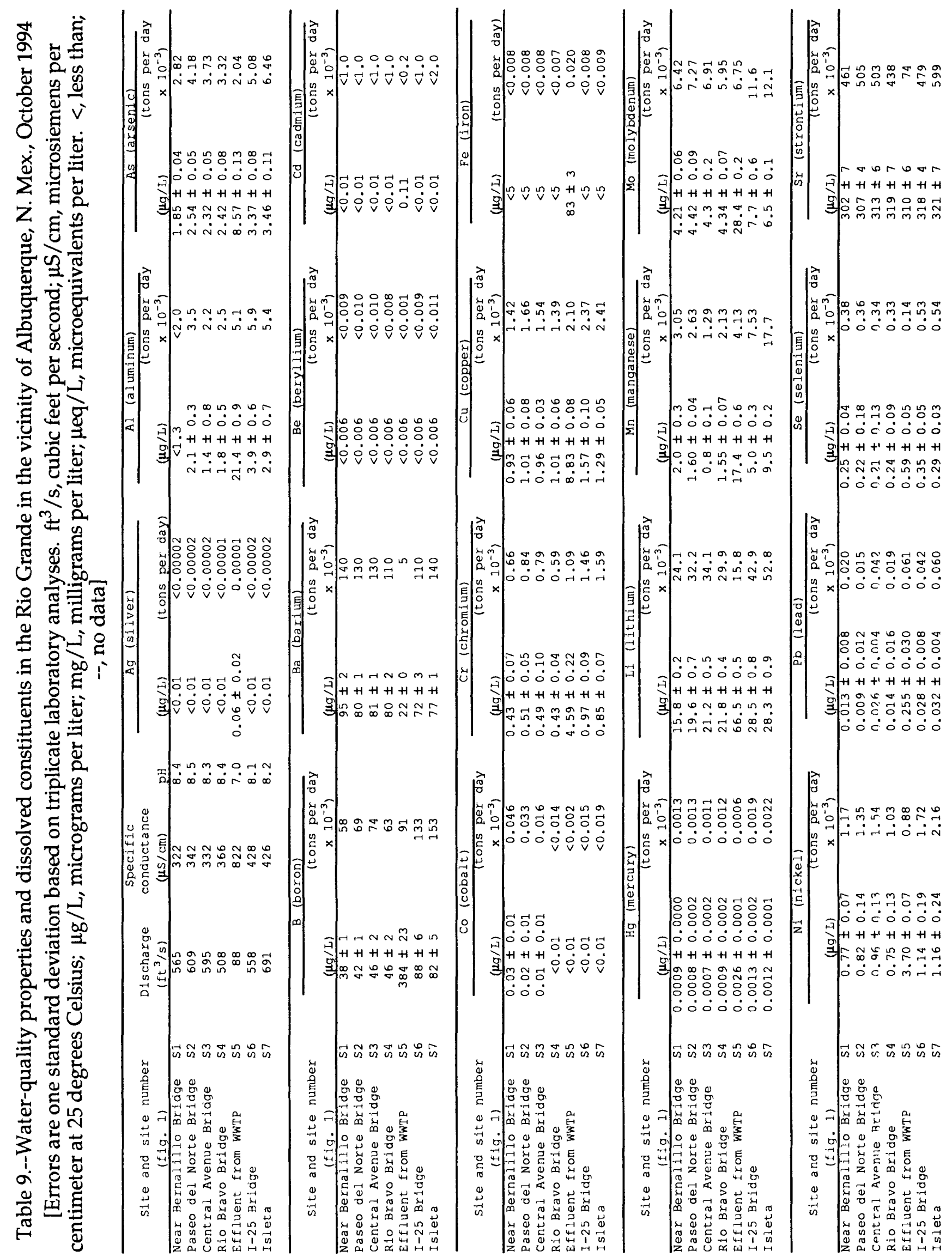




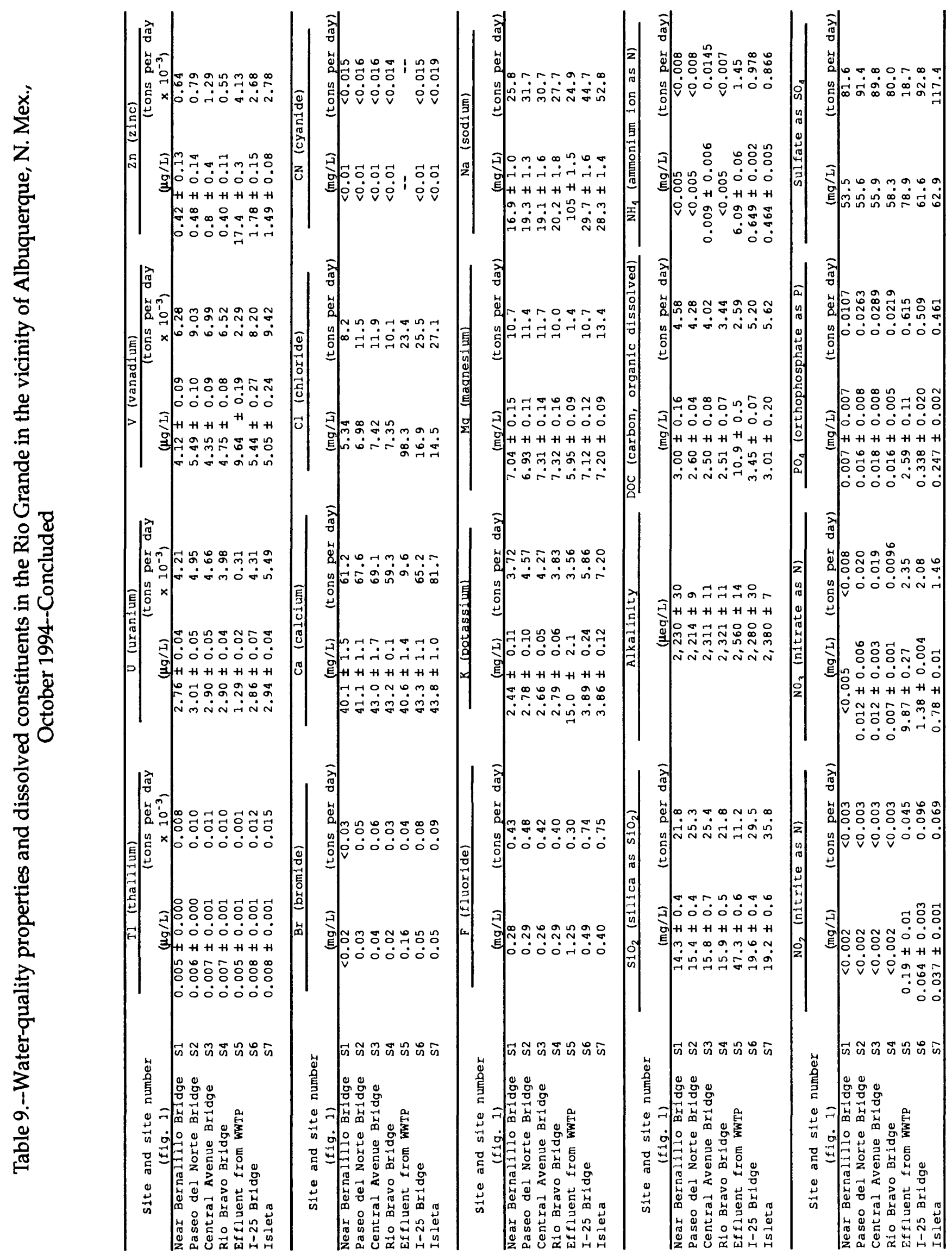




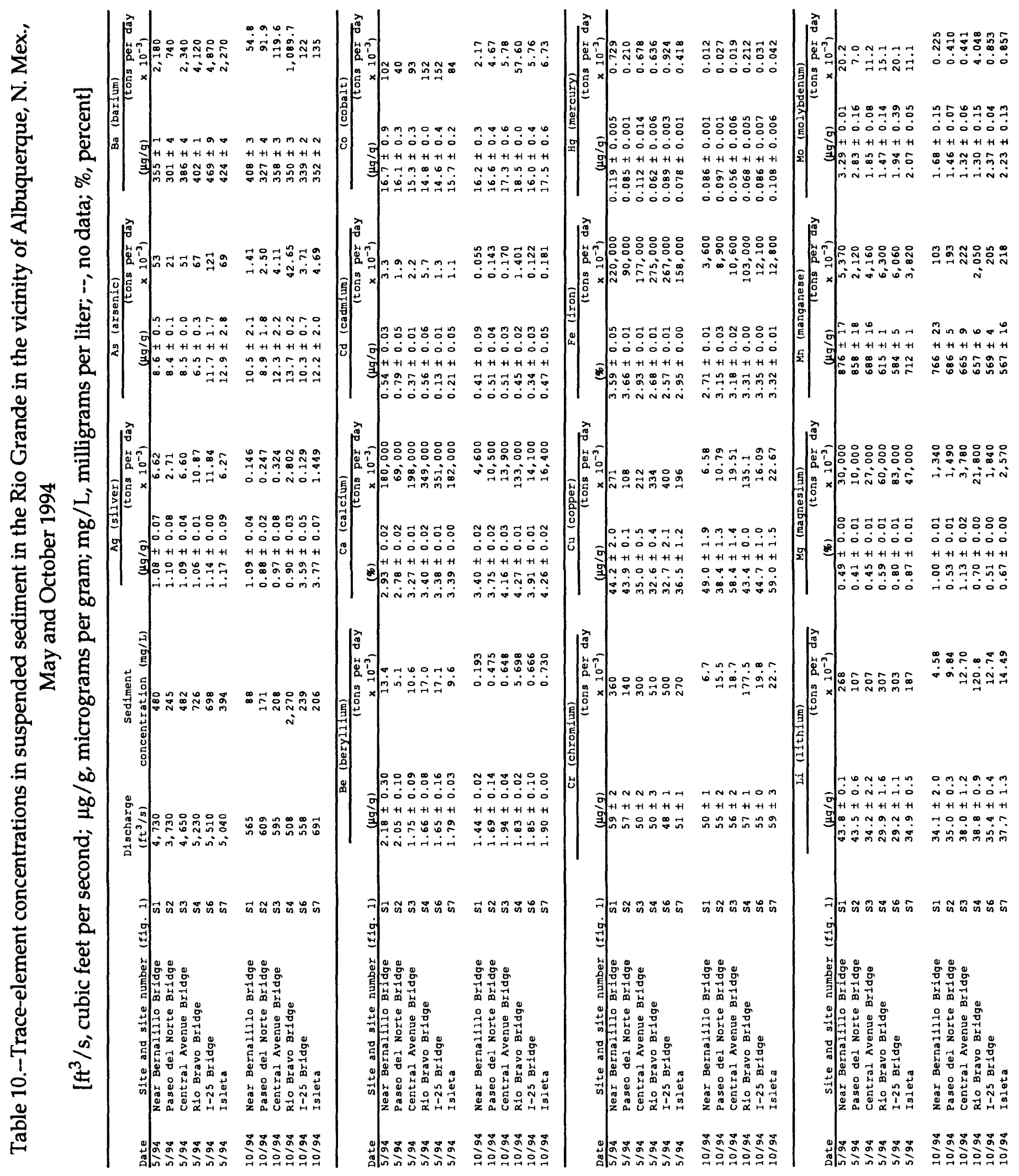




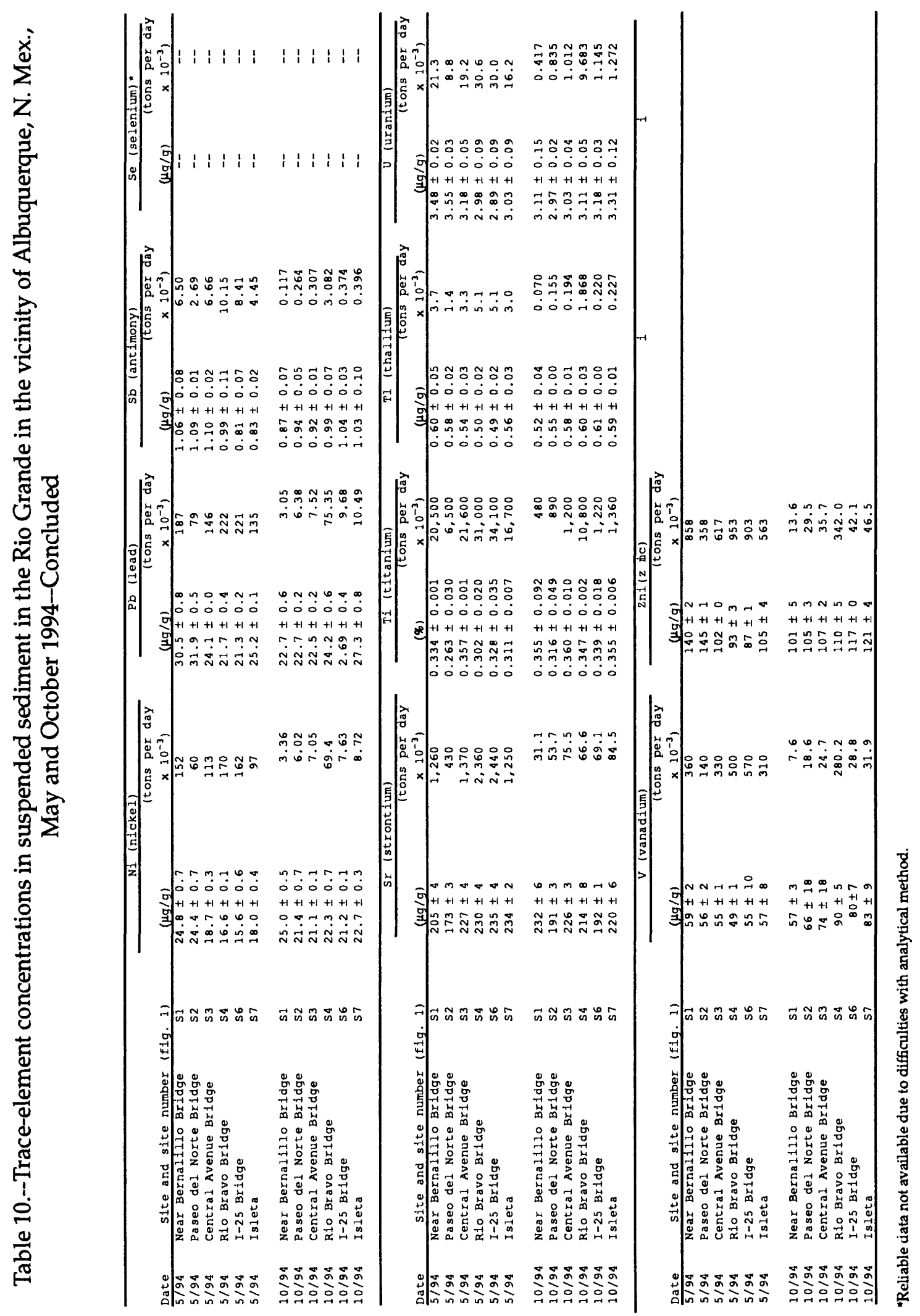




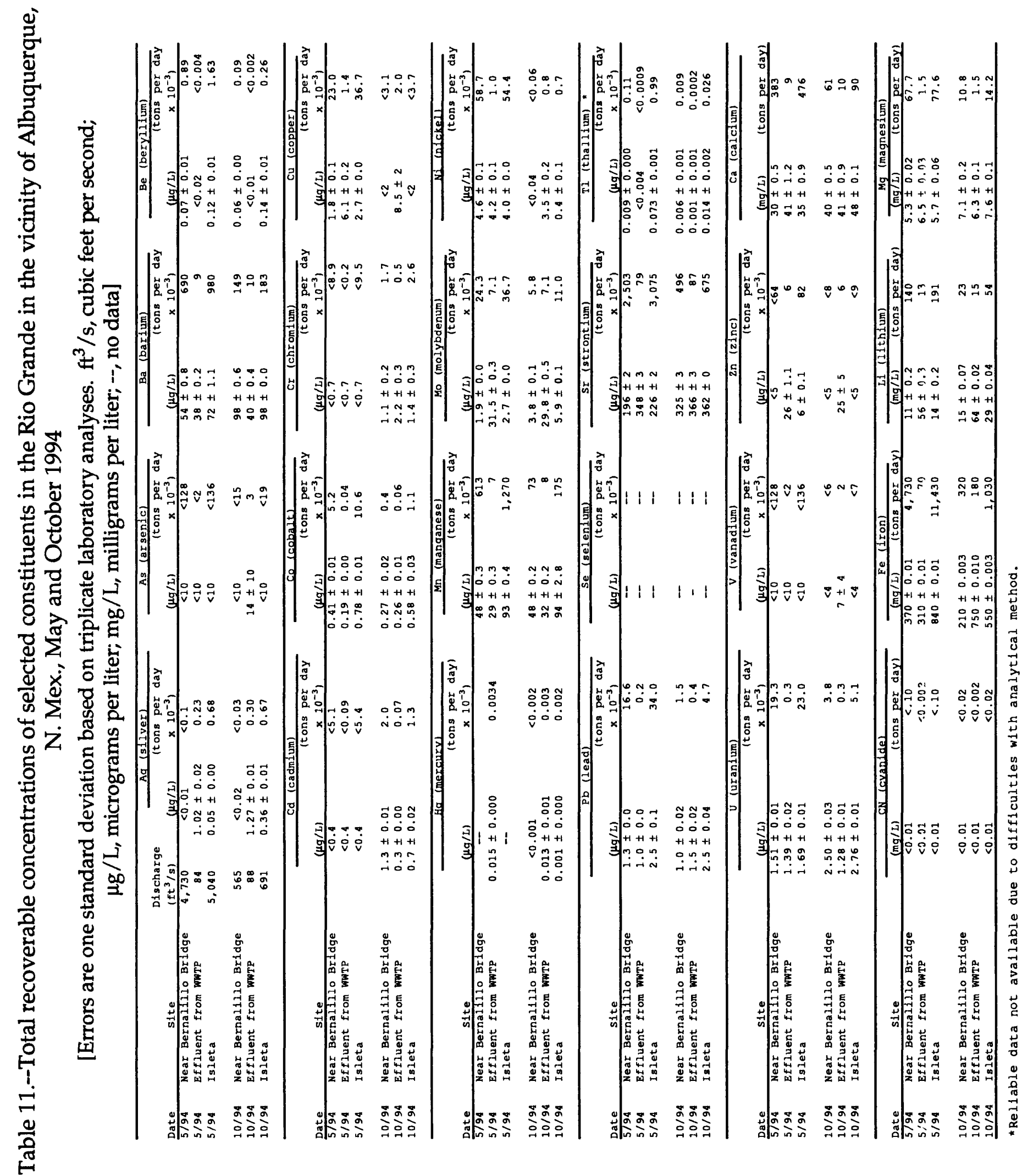


Table 12.-Minimum reporting limits for selected dissolved trace elements used in this study and those previously reported by the U.S. Geological Survey

[All values reported in micrograms per liter]

\begin{tabular}{llc}
\hline \multicolumn{1}{c}{ Trace element } & Values for this study & $\begin{array}{c}\text { Values previously reported by } \\
\text { U.S. Geological Survey }\end{array}$ \\
\hline Silver & 0.01 & 1.0 \\
Aluminum & 1.3 & 10 \\
Arsenic & 0.02 & 1.0 \\
Barium & 0.2 & 1.0 \\
Beryllium & 0.02 & 0.5 \\
Cadmium & 0.02 & 0.1 \\
Cobalt & 0.01 & 0.5 \\
Chromium & 0.4 & 0.5 \\
Copper & 0.05 & 0.5 \\
Mercury & 0.0004 & 0.1 \\
Molybdenum & 0.01 & 1.0 \\
Nickel & 0.03 & 1.0 \\
Lead & 0.009 & 0.5 \\
Selenium & 0.2 & 1.0 \\
Strontium & 0.1 & 0.5 \\
Thallium & 0.004 & 0.5 \\
Uranium & 0.03 & 0.01 \\
Vanadium & 0.02 & 1.0 \\
Zinc & 0.06 & 0.5 \\
\hline
\end{tabular}

